\title{
수도권과 부산/울산 주택가격 비동조화 현상과 원인
}

\section{백인걸* $\cdot$ 최영상**}

- 주택가격의 지역적 차이는 전국적 범위의 경제·주택정책에 대한 지역별 민감도와 지역 고유특성 등에 따라 주기적으로 나타나며, 그 정도에 따라 동조화 및 비동 조화 되는 경향을 보임

- 본 연구는 동적요인모형(Dynamic Factor Model)을 사용하여, 동조화의 정도를 전국요인에서 비동조화의 요인을 지역요인에서 찾고자 함

- 연구결과 2004-2009년 간 전국요인이 견인하는 동조화 현상이 전국적으로 강하 였으나 2010년을 기점으로 점차적으로 지역요인이 강화되어 2015년 이후 비동 조화 현상은 더욱 뚜렷해짐

- 2010년 전후하여 지역요인이 강화되는 경향은 주택시장의 구조적이고 근본적인 변화와 더불어 수급의 불균형, 정부의 규제정책, 지역개발 정책 등 여러 가지 요 인이 지역 차별적으로 작용한 결과

- 부산주택시장의 지역요인 강화는 부산지역의 고유성에 기인하고 있는 것으로 보 이며, 지역요인의 강화는 도심재개발 및 혁신도시를 비롯한 지역개발 등이 큰 영 향을 미친 것으로 보임

- 울산 지역요인의 강화는 인구구조 및 경제상황, 주택시장 수급불균형 및 산업 도 시적 특성 등의 요인들이 영향을 미친 것으로 보임

- 주택시장 비동조성의 강화 경향과 이유를 분석한 본 연구는 향후 전국단위 주택 정책과 지역단위 주택정책의 차별적인 수립·관리가 왜 필요한지에 대한 근거로 활용이 가능할 것으로 보임

핵심어 전환기, 주택정책, 분양구조, 주택공급, 자금조달, 유동화

* 한국주택금융공사 백인걸 연구위원 (051-663-8171 / bingul@hf.go.kr)

** 한국주택금융공사 최영상 연구위원 (051-663-8172 / choiys@hf.go.kr)

※ 본고는 한국주택금융공사 주택금융연구원의 조사연구 보고서로 본지에 특별논고로 게재함 


\section{I . 연구배경}

$\square$ 2017년을 기점으로 주택시장이 서울 강남권을 중심으로 상승하였으며, 상승세는 점차 강북 그리고 서울과 인접한 경기지역으로 전이되기 시작

- 2018년에도 서울 전역 및 일산, 분당 등의 국지적 급등세가 지속되었으며 대구·광주·대전 등 지역 시장도 상승세에 가세함

$\square$ 수도권의 주택시장 버블에 대한 우려에 정부는 투기수요억제를 위해 금융·조세·주택시 장 전반에 걸친 대응에 들어갔으며, 중장기적인 안정화를 위해 3기 신도시 개발계획, 용 적률 규제완화 등의 공급확장정책까지 발표

- 2017년 6.19대책을 시작으로 조정대상지역 선정에 들어갔으며, 10.24대책을 통해 新DTI, DSR 도입, 2018년 6월 보유세 개편, 그리고 최근 9.13 대책을 통해 주택시장 안정대책을 연이어 발표함

$\square$ 정부의 적극적 대응으로 인해 2019년부터 버블이 우려되던 지역은 주택 수요와 공급의 동시침체로 인한 가격 조정세 지속

- 수도권은 주택구매 및 보유 부담과 시장 불확실성 확대가 거래절벽으로 이어져 2019년 5 월 기준으로 하락세가 지속되고 있음

$\square$ 하지만 수도권 및 일부지방의 상승세에도 불구하고 부산·울산·경남(부울경)의 주택시 장은 2017년 중순부터 공급과잉과 기반산업 침체 등으로 인해 하락세 지속

- (과잉공급) 2019년 3월 기준 시도별 미분양 현황(〈그림1〉)을 보면 경남이 14,824호, 부산 이 5,296호로 각각 같은 급의 행정단위 구역 중 가장 높은 미분양을 기록함

- (경기침체) 지역 기반산업인 조선·자동차·기계부품 관련 산업이 불황이 장기간 지속됨

- 2018년 한 해 동안 업무상업시설과 공업시설의 경매물건이 2017년에 비해 24.6\% 급증 함 $(14,308 \rightarrow 17,823)$

$\square$ 2017년 중순부터 2018년까지의 주택시장을 종합해보면 수도권 가격급등에 의한 과열 현상이 한동안 지속된 반면, 부울경 지역은 경기침체와 함께 주택시장 또한 냉각되었음 


\section{<그림 1> 시도별 미분양 현황}

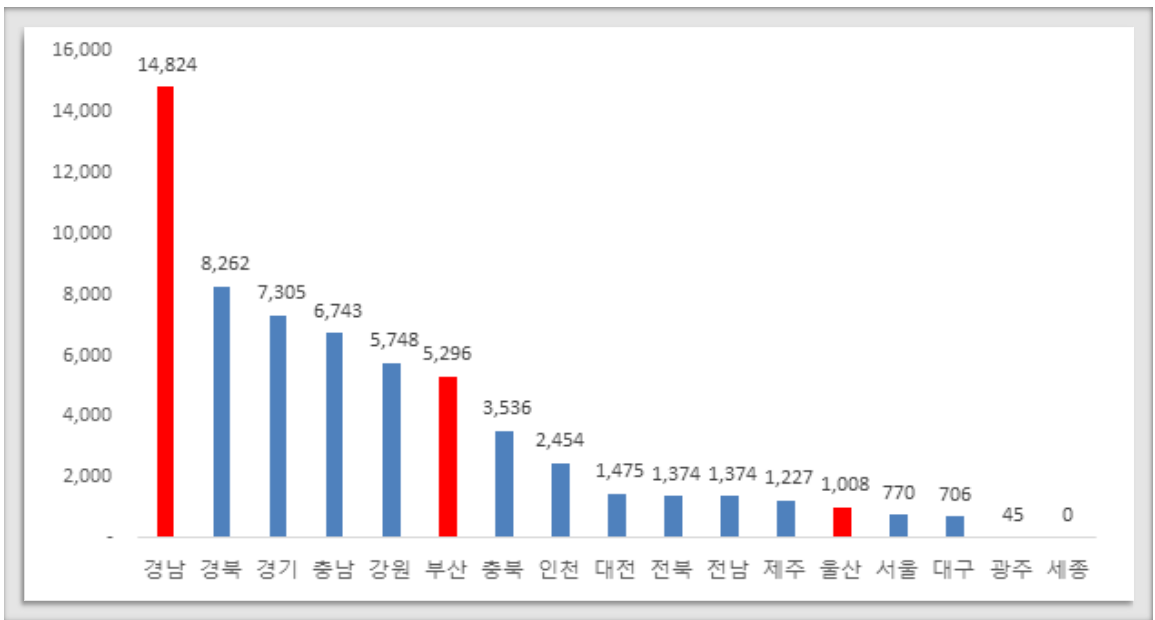

※ 자료 : 국토교통부, 2019년 3월 기준

이렇듯 공간적 차별성을 가지고 주택가격의 움직임이 서로 다르게 나타나는 현상을 흔 히 비동조화 현상이라고 정의함

- 일반적인 비동조화의 정의는 특정 자산집단 수익률의 상관관계가 정규적인 패턴을 벗어날 때를 말함

-〈그림2〉의 지역별 주택종합 매매가격지수를 보면 2017년 중순부터 2018년 말까지 양의 상관관계가 음으로 전환된 것을 확인할 수 있어, 수도권과 지방 주택시장간 비동조화가 발생하였음을 알 수 있음

\section{<그림 2> 주택종합 매매가격지수}

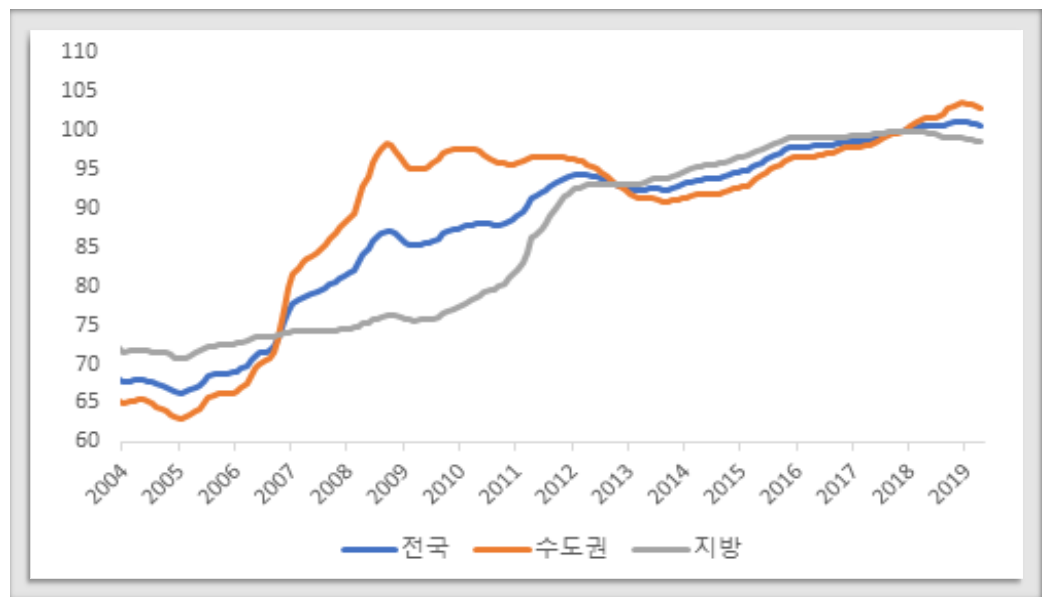

※ 자료 : 한국감정원, 2003.11-2019.4, $(2017.11=100)$ 
$\square$ 하지만 수도권과 지방 주택시장의 비동조화 현상은 비단 최근의 현상만은 아니며, 2000 년대 이후 크게 3번의 지역별 교차적 급등락 현상을 보임

-〈그림2〉의 명목 주택종합 매매가격지수를 보면 2005년부터 2008년까지 수도권은 급등세 를 보인 반면 지방은 안정세를 보임

- 2008년 이후 2012년까지 수도권은 안정기에 들어갔으나 지방은 이전과 다르게 급등세를 보임

- 이전만큼의 규모는 아니지만, 2017-2018년 수도권과 지방의 비동조화가 발생함

$\square$ 비동조화 현상을 반영하여 학계에서는 지역별로 차별화된 주택가격 결정요인 분석 등의 지역주택경제연구가, 정책입안자 입장에서는 국지적 주택가격 급등 시 지역맞춤형 주택 안정화 정책을 발표함

- 2017년 국지적 과열현상이 나타나자 정부는 6.19, 8.2, 9.5 대책을 연이어 발표하며, 지역 별 규제에 차별화를 둔 조정대상지역, 투기과열지구, 투기지역을 발표

무거안정이라는 사회가치와 직결되는 필수적인 요소이기에 주택시장의 지역별 차이를 이해하기 위해 보다 엄밀한 주택시장의 비동조화에 대한 정의와 연구가 요구됨

- 단순히 가격의 방향성을 가지고 동조화 혹은 비동조화를 논하였지만 실제 가격의 움직임이 란 주택시장 고유의 수급변화와 같은 내적요인과 정부규제 등의 외적요인에 의해 지역주택 시장의 방향성이 결정됨

- 따라서 실제 동조화라 정의할 수 있는 경우는 피상적 결과물인 가격의 움직임으로 판별하 는 것이 아니라, 전 지역의 주택가격의 변화를 설명하는 특정한 공통요인의 지역별 주택가 격에 대한 설명력이 클 때를 말함

$\square$ 본 연구에서는 동적요인모형(Dynamic factor model)을 사용하여 서울, 부산, 대구, 광주, 대전, 울산, 경기의 총 97 개 행정구역 주택가격의 동조화를 유발하는 잠재요인을 식별하였으며, 이를 바탕으로 관심지역인 수도권과 부산/울산 지역 주택시장의 역사적 동조화와 비동조화 흐름을 분석함

- 동적요인모형은 각 지역의 주택가격 변화율을 전국요인과 지역요인으로 분리 추출하여 지 역 간의 비동조화 현상을 분석함

- 상호독립적인 전국요인과 지역요인은 지역의 주택가격 변화율에 내재된 전국적 흐름과 지역적 흐름을 시계열 단위로 식별해 냄 


\section{II . 선행연구}

주택가격의 동조화에 대한 국내 선행연구는 연구대상의 범위에 따라 1) 서울 중심의 행 정단위 분석 혹은 2) 국가단위로 분류됨

- (행정단위)

- (이용만·이상한, 2004): 강남아파트 시장의 가격 전이효과를 자산가격이론에 기초하여 검증함. 공적분 검증결과, 강남지역과 비강남지역의 주택가격간에 장기적 관계가 존재하 지 않는 것으로 나타남

- (문규현·이동현, 2011) 강남아파트 시장과 전국아파트 시장 사이의 선도/지연 관계를 벡 터자기회귀모형을 사용하여 규명함. 그레인저 인과관계분석결과 1998년 이전은 강남매 매 전세시장이 전국을 선도하였으나, 그 이후 이 현상이 많이 사라짐을 보임

- (국가단위)

- (황상연·차경수, 2014) 국내 25개 지역주택가격간의 동조성을 견인하는 주도지역의 존재 여부를 주성분분석(Principal component Analysis)을 통해 분석함. 그 결과 외환위기 이후 기간 중 주택매매가격은 서울-강남, 천안, 광주 지역이, 전세가격의 경우는 서울-강 북 지역이 주도지역으로 식별됨

- (신용상, 2015) 외환위기 이후의 수도권과 비수도권 지역 간 비대칭적 주택가격 변화에 영향을 주는 요인들을 수급·규제·기술적 요인으로 구분하여 살펴봄. 2000년대 이후 수도 권-비수도권 간의 현저하게 비동조화 된 가격흐름 존재하였으며, 전세가, 지역 소득수준, 주택 잠재수요 및 구매력 수준, 미분양주택 수 등이 중요한 요인으로 발견됨

국제단위의 해외연구(〈표1〉)는 주로 세계화로 인한 경제통합을 연결고리로 하여 국제 주택시장 간의 동조화 매커니즘을 밝히고자 함

- 경제통합으로 인해 각 국의 통화정책, EU의 통화통합, 무역자유화, 국제신용시장의 확대, 지정학적 불확실성 공유 등의 전 세계적 파급효과를 중심으로 동조화 결정요인을 분석 


\section{<표 1> 해외 주택시장 동조화 주요 선행연구}

\begin{tabular}{|c|c|c|}
\hline 저자 & 주제 & 주요 결론 \\
\hline $\begin{array}{l}\text { Pomogajk } \\
\text { and } \\
\text { Voigtländer } \\
\text { (2012) }\end{array}$ & $\begin{array}{l}\mathrm{OECD} \text { 국가들의 } \\
\text { 주택가격 동조화 }\end{array}$ & $\begin{array}{l}\text { - 동조화 원인: 세계화와 통화통합 } \\
\text { - 기간을 구분한 분석결과, 최근 } 10 \text { 년 동안 동조화 심화 } \\
\text { - 주거용 부동산투자는 인플레이션 헤지의 수단 } \\
\text { - 위험관리수단으로서 타국의 주거용부동산에 투자 } \rightarrow \\
\text { 국제 주택가격의 동조화 촉진 } \\
\text { - 유럽의 통화통합은 이러한 국제주택가격의 동조화를 더욱 심화 } \\
\text { - 독일/네덜란드/일본은 디커플링(decoupling) }\end{array}$ \\
\hline $\begin{array}{c}\text { Gupta et al. } \\
\text { (2015) }\end{array}$ & $\begin{array}{l}\text { 유럽지역 8개국 } \\
\text { 주택가격의 } \\
\text { 동조화 }\end{array}$ & $\begin{array}{l}\text { - 동조화 원인: 경제통합과 통화통합 } \rightarrow \text { 소득 및 이자율의 변화 } \\
\text { - 주택가격간 공적분 관계를 갖는 국가들의 쌍 파악 } \\
\text { - 벨기에/스페인, 벨기에/네덜란드, 독일/스페인, 독일/아일랜드, } \\
\quad \text { 프랑스/스페인, 네덜란드/아일랜드 } \\
\text { - 독일의 주택가격은 다른 나라와 반대 } \\
\text { - 경제통합 특히 통화통합은 이자율 및 소득에 영향 } \rightarrow \\
\text { 주택가격에 영향 }\end{array}$ \\
\hline $\begin{array}{l}\text { Hirata et al. } \\
\qquad(2013)\end{array}$ & $\begin{array}{c}\text { 18개 국가의 } \\
\text { 주택가격의 } \\
\text { 동조화, } \\
\text { 글로벌 주택가격 } \\
\text { 충격요인 }\end{array}$ & $\begin{array}{l}\text { - 동조화 원인: 이자율, 통화정책, 생산성, 신용 그리고 불확실성을 포 } \\
\text { 함하는 다양한 글로벌 충격 } \\
\text { - 선행연구들은 채용된 계량기법에 따라 동조화의 원인 또는 경로를 } \\
\text { 명시적으로 확인 곤란 } \\
\text { - VAR, GVAR, FAVAR } \\
\text { - Standard recursive 기법과 부호제약(sign restriction)을 통해 } \\
\text { 동조화의 원인을 파악 } \\
\text { - 이자율 및 통화정책, 생산성, 신용, 불확실성 등의 글로벌 충격은 } \\
\text { 유의미 하지 않음 } \\
\text { - 주택가격에 있어서는 불확실성 중요하며, 동조화가 존재하고, 시 } \\
\text { 간의 흐름에 따라 증가함 }\end{array}$ \\
\hline $\begin{array}{l}\text { Otrok and } \\
\text { Terrones } \\
\text { (2005) }\end{array}$ & $\begin{array}{l}\text { 주택 가격과 } \\
\text { 이자율 및 거시 } \\
\text { 경제변수간 관계 }\end{array}$ & $\begin{array}{l}\text { - 동조화 원인: 이자율 역할 중요 } \\
\text { - 이자율에 대한 동태적인 공통 성분과의 관계 존재 } \\
\text { - 주택가격이 거시경제변수들에 영향을 미침 }\end{array}$ \\
\hline $\begin{array}{c}\text { Kim and Park } \\
\text { (2016) }\end{array}$ & $\begin{array}{l}\text { 동아시아 및 } \\
\text { 중국권의 } \\
\text { 주택가격 경기의 } \\
\text { 특성 }\end{array}$ & $\begin{array}{l}\text { - 동조화 원인: 통화 및 재정정책, 신용공급, 국제거래개방도 및 경기 } \\
\text { 순환변동 } \\
\text { - 동아시아 주택가격은 세계주택가격 경기순환과 강하게 동조화, 단기 } \\
\text { 엔 상대적으로 약함. } \\
\text { - 지역요인 및 국제거래 개방도가 중요한 원인이나 요인별 영향력은 } \\
\text { 나라마다 다름 } \\
\text { - 홍콩, 대만 및 싱가포르는 중국권(Greater China) 효과 존재 }\end{array}$ \\
\hline
\end{tabular}

※ 자료 : 조무상, 이종하 (2018) 


\section{III. 계량모형}

\section{1. 모형}

$\square$ 본 연구의 분석방법은 크게 동조화를 유발하는 잠재요인 추출과 이를 바탕으로 통계적 추정으로 구성됨

1) 행정단위 주택가격의 움직임을 설명하는 요인을 전국요인과 권역요인으로 나누어 분리추 출하기 위해 상태공간모형(State-space model)의 형태를 가진 시계열 모형을 사용함

- 일반적으로 선형회귀모형과 같이 설명하고자 하는 대상이 단지 몇 가지 독립변수에 의해 결정된다는 제한적인 가정을 피하고자 공통요인을 주택가격 변화율 자체에 내재되어 있 는 잠재요인으로 설정하여 전국 및 권역요인을 추정함

2) 추정된 전국요인과 각 지역요인을 바탕으로 시간의 흐름에 따라 변화되어 온 각 지역 주택 가격의 동조화와 비동조화 현상을 분석함

- 추정된 잠재요인의 주된 변화를 기준으로 각 지역 주택가격 변화율에 대한 전국 및 지역 요인의 설명력을 측정하기 위해 분산분해를 적용함

잠재요인을 추출하기 위해 Otrok and Whiteman(1998)이 고안한 베이지안 기법을 적용한 동적요인모형(Dynamic factor model)을 사용함

- 동적요인 모형의 주목적은 총 97개의 최소 행정단위 지역 주택가격 변화율로부터 주택 매 매가격에 내재되어 있는 전국 공통요인과 기타 지역적 요인을 독립성을 보장한 채 추정하 는 것임

동적요인모형은 주택가격의 급등, 즉 버블이 의심될 때 이것이 전국요인에 의한 동조화 현상인지 혹은 단지 지역요인에 국한된 현상인지 구분이 가능함

- 예를 들어 $\mathrm{A}$ 와 $\mathrm{B}$ 의 두 인접한 지역의 부동산이 급등하였다고 가정한다면 일반적인 시각에 서 이것은 두 지역의 동조화가 발생하여 주택가격이 상승한 버블현상으로 볼 수 있음

- 하지만 A지역의 상승 대부분은 전국적 통화확장 정책에 의해 발생한 버블이라 전국요인이 상승에 기여한 바가 크고, B지역의 경우 지역 주택시장의 수급상황에 의한 급등현상이라 지역요인에 의해 주택가격 상승분이 설명되는바가 크다면, 두 지역은 비록 육안 상으로는 
동조화지만 실제로 전국적 요인에 의한 동조화가 아니기에 전혀 다른 정책적 대안이 필요 할 것임

\section{또한, 동적요인모형은 경제변수선정과 지역선정 문제에 있어 자유로움}

- 많은 선행연구는 동조화 현상에 자체에 집중하기 보다는 동조화를 발생시키는 요인들에 대 한 연구가 주를 이루었음

- 그러한 연구에 쓰이는 방법론은 경제변수나 지역선택에 따라 결과가 민감하게 반응하여 신 뢰도 있는 결과를 얻기 힘듦

$\square$ 기본적으로 관찰 가능한 변수인 주택가격 변화율은 전국요인, 권역요인(광역시 혹은 경 기도), 고유충격(광역시 구 혹은 경기도 시)의 선형결합으로 구성되어 있다고 가정하며 아래와 같이 표현함

$$
y_{n, t}=\beta_{n}^{0} f_{t}^{0}+\sum_{r=1}^{R} \beta_{n}^{r} f_{t}^{r}+\epsilon_{n, t}
$$

- 주택가격 변화율: $y_{n, t}, n=1, \ldots, N, t=1, \ldots, T$

- 전국요인 $\left(f^{0_{t}}\right)$, 권역요인 $\left(f^{r_{t}}\right)$, 고유충격 $\left(\epsilon_{n, t},\right): n=1, \ldots, N, t=1, \ldots, T$

- 즉, 주택가격 변화율 $\left(y_{n, t}\right)$ 은 국가적인 현상에 의해 결정되는 전국요인, 지역 고유의 인구 구조적 변화, 경제성장 등과 같은 역사적 추세 정보와 추세를 벗어난 변동률의 결합임

- 본 연구에서 중점을 두고 있는 것은 역사적 평균 추세의 흐름이 아니라 얼마나 현재의 가 격변동이 평균에서 벗어나는지를 확인하고, 이러한 변동의 동인을 유발하는 잠재요인을 구분하는 것이기에 모형에 적용되는 주택가격 변화율은 장기평균값을 제거한 값 (Demeaned growth rate)임

$\square$ 요인계수(Factor loading)인 $\beta^{0_{n}}$ 과 $\beta^{n_{n}}$ 은 각각 전국요인과 권역요인에 대한 민감도를 나타내며, 지역 요인계수 $\left(\beta^{r_{n}}\right)$ 값은 시구단위 $n$ 이 지역 $r$ 에 포함되지 않으면 0 의 값을 가진다고 가정함

- 예를 들어, 부산 해운대구의 권역요인 값에 의해 부산 이외의 지역의 주택가격 상승률이 결 정되지 않는다는 것을 뜻함 
$\square$ 주택가격의 변화율을 결정하는 모든 잠재요인들은 아래와 같은 $A R(q)$ 과정을 따른다고 가정하며, 오차항의 표준편차를 1 로 제약함

$$
f_{t}^{r}=\phi_{1}^{r} f_{t-1}^{r}+\ldots+\phi_{q}^{r} f_{t-q}^{r}+u_{t,}^{r} u_{t}^{r} \sim N(0,1), r=0,1, \ldots, R
$$

잠재요인의 자체적 프로세스 오차항의 확률분포에 제약을 주는 이유는 연속적으로 추정 해야하는 요인계수와 잠재요인이 곱의 형태로 결합되어 있어 부호(Sign)와 크기 (Scale)를 고려하여 분리 식별(Identification)하는 것에는 방법론적인 한계가 존재하 기 때문임

- 이러한 식별의 문제점을 해결하기 위해 추정 모수에 사전적 제약을 주어야 하는데 이때 쓰 일 수 있는 방법이 두 가지가 있음

- 첫 번째는 임의로 선택된 지역의 전국요인 factor loading $\left(\beta_{n}^{0}\right)$ 을 1 로 고정시키는 방법 임. 하지만 요인계수를 상수로 고정시킨다면 잠재요인에 대한 불안정한 사후분포 (Posterior)를 형성할 수 있는 문제가 발생함(Waggoner and Zha(2003))

- 두 번째 해결방법은 오차항 $\left(u^{r_{t}}\right)$ 의 분산은 1 로 정규화하고 주택가격 선도지역의 요인계수 $\left(\beta_{n}^{0}\right)$ 의 부호를 양의 값으로 제약을 두는 것임.1) 이 방식의 유일한 단점은 추정된 잠재요 인 자체의 값에 어떠한 경제적 의미를 두기 힘들다는 것이지만, 잠재요인과 결합하는 추 정계수와의 곱 $\left(\beta^{0_{n}} f^{0_{t}}\right)$ 은 전국요인이 지역 주택매매가격 변화율에 기여하는 요소로 직접 적으로 해석되기에 큰 문제가 되지 않음

고유충격은 $\mathrm{AR}(\mathrm{pn})$ 프로세스를 따르며 (식 3)과 같이 표현됨. 동적요인모형은 전국 혹 은 지역 동조화 요인 $\left(f_{t}\right)$ 과 지역자체의 충격 $\left(\epsilon_{n, t}\right)$ 을 분리하는 것을 목적이기에 잠재요 인과 충격의 오차항은 상호독립적이라는 것이 중요한 가정임

$$
\epsilon_{n, t}=\phi_{n, 1} \epsilon_{n, t-1}+\cdots+\phi_{n, p} \epsilon_{n, t-p}+u_{n, t}, u_{n, t} \sim N\left(0, \sigma_{n}^{2}\right)
$$

- 만일 한 지역의 고유충격 프로세스의 오차항이 잠재요인 혹은 다른 지역의 오차항과 상관

1) 여러 선행연구에 따라 강남과 같은 선도지역 주택가격 변화율이 전국적 가격등락을 결정하는 요인과 양의 관계를 가진 다는 것은 합리적인 가정임 


\section{주택금융연구 VOL 3}

관계를 가지고 있다면, 더 이상 지역(광역시 구 혹은 경기도 소규모 시) 고유의 특징을 담고 있는 분석이 가능하지 않음

- 따라서 (식 4)와 같이 표현되어 전국요인과 지역요인 오차항의 직교성을 보장함. 고유충격 프로세스와 마찬가지로 이 가정이 유지되지 않는다면 요인 간의 고유한 특징을 담을 수 없 게 됨

$$
E\left[u_{t}^{r} u_{t}^{s}\right]=0 \text { for all } r, s, t
$$

\section{2. 주택가격 변화율 vs. 잠재요인}

$\square$ 본 장에서는 동적요인모형을 통해 추출한 전국요인 혹은 지역요인이 전국 혹은 지역 주 택 매매가격지수와의 차이점을 살펴보고, 주택가격 대신 동조화 분석에 잠재요인을 사 용하는 당위성을 알아보고자 함

$\square$ 제본스 지수(Jevons index) 작성법을 적용한 한국감정원에서 제공하는 매매가격지수 의 구조를 살펴보면, 주택가격지수 상승률은 작은 단위 구역의 가중치와 그 성장률의 가 중평균으로 도출되며 동적요인모형에 적용하면 (식 5)과 같이 표현됨.2)

$$
\sum_{n} w_{n} y_{n, t}=\left(\sum_{n} w_{n} \beta_{n}^{0}\right) f_{t}^{0}+\sum_{n} w_{n}\left(\sum_{r=1}^{R} \beta_{n}^{r} f_{t}^{r}+\epsilon_{n, t}\right)
$$

$\square$ 마지막 항인 $\sum w_{n}\left(\sum \beta_{n}^{r} f_{t}^{r}+\epsilon_{n, t}\right)$ 가 영의 값을 가질 때만 전국요인과 전국 주택 매매 가격지수 간에 완벽한 상관관계를 가짐

- 하지만 이러한 경우는 각 지역에 대한 가중치가 매우 작아 대수의 법칙(Law of Large numbers)에 의해 고유충격요인이 사라지는 경우이기에 현실에서는 적용되기 힘듦

$\square$ 가중치는 재고주택수를 기준으로하기에 서울 혹은 경기도 특정지역의 경우 이 값이 상 당히 클 수밖에 없어, 만일 전국 그리고 지역 고유의 주택시장의 특성을 연구하는 목적에

2) 주택 매매가격지수의 변화율은 $y_{t}=\sum w_{n} y_{n, t}(n=1, \ldots N)$ 이며 $w_{n}$ 은 지역별 주택재고량을 고려한 가중치, $y_{n, t}$ 는 더 작은 단위지역의 매매가격 변화율임 
주택가격 지수를 사용한다면 가중치가 높은 지역에 편중된 분석결과를 도출될 것임

따라서 우리는 동적요인모형을 통해 지역별 재고주택수에 의한 가중치를 제거한 공통된 잠재요인을 추출하는 것에 목적을 둠

\section{3. 분산분해 및 모수추정}

$\square$ 모든 지역 주택가격변화율 $\left(y_{n, t}\right)$ 의 움직임을 전국요인에 대한 분산분해(식 6)을 추정하 여 전국요인이 특정기간 동안 지역주택가격의 변동성에 미치는 영향력 정도를 분석함

$$
v_{n}\left(t_{0}, t_{1}\right)=\frac{\sum_{t=t_{0}}^{t_{1}}\left(b_{n}^{0} f_{t}^{0}\right)^{2}}{\sum_{t=t_{0}}^{t_{1}}\left(b_{n}^{0} f_{t}^{0}\right)^{2}+\sum_{t=t_{0}}^{t_{1}}\left(b_{n}^{r} f_{t}^{r}\right)^{2}+\sum_{t=t_{0}}^{t_{1}} \epsilon_{n, t}^{2}}
$$

- 분산분해는 각 지역에 대해 총 조사기간(2004Q1-2018Q3) 그리고 우리의 관심기간인 동 조화와 비동조화의 강도가 변화하는 것을 기준으로 하여 3기간으로 나누어 분석함

동적요인모형을 결정짓는 잠재요인, 요인계수, 충격프로세스 관련 모수의 사후분포를 추정하기 위해 베이지안 추정기법 중 하나인 깁스 샘플링 (Gibbs sampling)을 사용함

- 깁스 샘플링은 한 모수집단의 조건부 분포로 부터 다른 모수집단을 연속교차하여 샘플링하 는 방식이며, 모든 모수의 결합사후분포(Joint posterior distribution)를 모르더라도 조 건부 사후분포(Conditional posterior distribution)를 알고 있다면 각 모수집단에 대한 사후분포의 연속적 반복 샘플링 기법을 통해 추출된 샘플은 결합사후분포에서 추출한 샘플 과 점근적으로 같아진다는 통계적 이론을 바탕으로 함

\section{$\square$ 깁스샘플링 단계}

1) 관심모수를 추정하기 위해 일단 모수를 샘플링하기 위해 잠재요인집단과 다른 기타 모수 집단(이하 모수집단)으로 나눔

2) Chib and Greenberg(1994)의 방법을 바탕으로 잠재요인들을 조건부로 한 AR(p)과정 의 오차항을 가진 회귀모형에서 모수집단을 샘플링함 
- 모든 오차항이 독립적이라는 가정에 따라 샘플링은 각 지역에 상응하는 식마다 시행하면 되며, 같은 과정을 $\phi^{r_{j}}$ 에 적용하여 샘플링함

3) 앞 단계에서 추출한 모수집단을 조건부로 하여 모든 잠재요인을 추출함. 모수집단을 조건 부로 하면 앞서 언급된 모형은 상태공간모형을 따르기에 Carter and Kohn(1994)의 기 법을 따라 잠재요인을 추출함

4) 2)와 3)의 과정을 반복수행하여 잠재요인 및 모수에 대한 사후분포를 추정하여 통계적 분 석에 활용함

모든 시계열적 요인과 모수의 사후분포를 추정하기 위해 사전분포(Priors)는 Kose et al. (2003)의 기본적 형태를 따른다고 가정함

- $\beta^{{ }^{n}}$ 의 사전분포는 평균 1 , 분산 1 인 정규분포를 따르며, 고유충격의 오차항은 모수 12 와 0.002 인 역감마 분포를 따름

- 모든 AR과정의 첫 번째 시차에 상응하는 계수에 대한 사전분포는 평균 0 , 분산 1 인 정규분 포를 따르며 시차가 늘어갈수록 그에 대한 분산은 0.5 의 승수를 거치며 감소함

- 잠재요인 AR과정의 시차(q)는 3이며 고유충격 과정의 시차(p)는 2를 따르며, 마지막으로 모든 사전분포는 상호 독립적이라고 가정함

\section{4. 조사자료}

$\square$ 한국감정원에서 제공하는 주택가격매매지수는 임대주택을 제외한 전국의 재고 아파트 와 거래 가능한 연립주택 및 단독주택을 대상으로 총 27,502 호의 표본으로 작성됨

$\square$ 계량모형을 다룬 장에서 설명하였듯이 주택가격매매지수는 제본스 지수 방법론을 적용 하여 최소공표단위지수를 기준시점 조사가격을 기준으로 기하가중평균 방식으로 산출 한 후, 같은 방법으로 광역단위의 주택가격매매지수를 계산함

- 한국감정원의 부동산통계정보는 총 176 개의 시군구에 대한 종합 주택가격매매지수를 제공 하나 본 연구의 분석지역은 6대 특별·광역시(서울, 부산, 대구, 대전, 광주, 인천)의 구단위 와 경기도의 시단위로 한정함 
- 서울 25 개구, 부산 15 개구, 대구 8 개구, 인천 8 개구, 광주 5 개구, 대전 5 개구, 울산 5 개 구, 경기 26개시로 총 지역 수는 97개임

또한 조사기간은 2004년 1분기부터 2018년 3분기까지로 정하여 최근 2000년대 수도 권, 2010년대 초기의 상승기를 포함하며 2017년 이후 주요 부동산 및 가계부채 대책기 간을 포함시킴

- 데이터 시작기간이 1986년인 $\mathrm{KB}$ 주택가격지수를 사용하여도 되나 $\mathrm{KB}$ 주택가격지수의 경 우 제공되는 행정구역의 수가 한국감정원에 비해 제한적이며 지역에 따라 시계열 시간이 짧기에, 데이터 구조가 일관성이 있으면서 많은 지역을 다룰 수 있는 한국감정원 데이터를 사용함

$\square$ 또한 본 연구의 목적은 최근에 발생하고 있는 지역 주택가격들 간의 상호 의존성을 분석 하는 것이기에 한국감정원의 주택가격매매지수가 $\mathrm{KB}$ 혹은 다른 출처의 자료보다 데이 터의 구조적 일관성과 다루는 지역의 다양함 측면에서 우월성을 가지고 있다고 판단됨

동적요인모형의 식별문제 해결방안 중 오차항의 분산에 대한 제약과 더불어 요인계수의 부호에 대한 제약이 필요하기에, 요인계수 부호제약 조건은 전국의 거점지역(1개)과 각 시 혹은 도 지역의 거점지역(8개)을 선정하여, 이 지역의 요인계수는 양의 값이라는 제 약을 함

$\square$ 거점지역 선정에는 가구원수, 선정지역의 지정학적 중요성, 혹은 계량적 선택 등 여러 가 지 방법이 있음

- 황상연·차경수(2014)는 비록 서울 구단위 행정구역을 모두 활용하지 않았지만 강남지역의 경우 외환위기 이후 전국적 주택가격을 선도하는 거점이라고 계량적으로 밝힘

- 이 외에 국내연구에서 거점지역 선정에 관한 연구는 찾아보기 힘들며 계량적으로 그 단위 를 전국적으로 확장하여 연구하기에는 다소 무리가 따름

- 서울의 경우 강남구를 나머지 지역의 경우 가구원수를 기준으로 하여 부산 해운대구, 대구 수성구, 인천 부평구, 광주 광산구, 대전 서구, 울산 남구를 거점지역으로 선정함

- 선정된 지역을 대상으로 하여 전국 거점지역의 요인계수와 각 지역의 거점지역 요인계수 (factor loading)의 부호가 양이 되도록 제약을 줌 
$\square$ 총 97개 지역의 월별 주택매매가격지수의 분기별 평균을 사용하여 분기 데이터로 변환 하였으며, 지역별 소비자 물가지수를 사용하여 실질 주택매매가격지수를 구함

- 단측 HP필터(One-sided HP filter)를 사용하여 주기성(Cycle)을 제거하였으며 로그차분 을 사용하여 주택가격에 대한 연간 상승률을 구함과 동시에 평균성장률을 제거하여 동적요 인모형에 적용함3)

\section{IV. 결과분석}

\section{1. 주택가격과 잠재요인의 역사적 흐름}

$\square$ 동적요인모형에 의해 각 지역의 주택가격 상승률은 전국요인, 권역요인 및 고유충격 부 분으로 분해됨

- 추정된 잠재요인인 전국요인과 권역요인은 요인에 대한 민감도를 나타는 요인계수와의 결 합을 통해, 각 잠재요인이 주택가격 변화율에 기여하는 정도를 보여줌

- 예를 들어 서울 강남구의 주택가격 변화율 중 전국요인이 주는 영향력은 추정된 전국요인

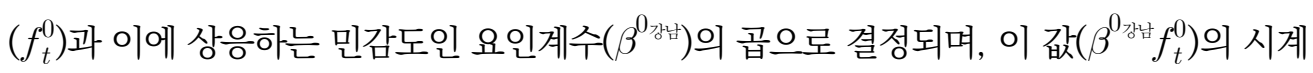
열은 전국요인이 강남 주택가격 변화율에서 차지하는 부분의 시간적 변화를 설명함. 위와 같은 방식으로 권역요인이 주는 영향력 또한 결정됨

- 계량모형에 의해 지역 공통의 요인과 최소행정단위의 고유충격이 구분되었지만, 고유충격 역시 세부 지역의 요소로 인식하여 여기서부터는 지역요인 $\left(\beta_{n}^{r} f_{t}^{r}+\epsilon_{n, t}\right)$ 을 정의하여 전국요 인과 비교하여 분석을 진행함

- 전국요인과 지역요인의 영향력은 $\beta^{0} f_{t}^{0}$ 와 $\beta_{n}^{r} f_{t}^{r}+\epsilon_{n, t}$ 의 추정된 사후분포의 중앙값을 사용함

$\square$ 〈그림3〉은 모든 지역의 주택가격과 이를 구성하는 전국요인과 지역요인의 시계열을 통 합적으로 보여주어 시기별 각 요인들의 변화를 보여줌

3) 본 연구에서 기본이 되는 계량모형은 현재 수치가 과거 정보에 의해 결정되는 시계열 과정을 따르기에 여기에

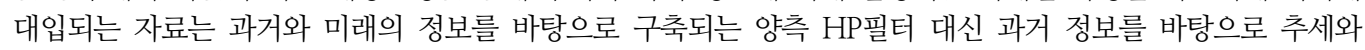
주기를 나누는 단측 $\mathrm{HP}$ 필터를 적용하였다. 
$\square$ 총 조사기간 동안 전국요인과 지역요인의 상대적 역할은 시기별로 큰 변화를 보이며 이에 따라 세 시기로 구분할 수 있음

- 〈그림3〉에서 말하는 요인들은 요인계수와 결합된 값으로 주택가격 변화율에 대한 영향력 을 의미함. 이하 의미상 혼돈이 있는 경우를 제외하고 편의상 요인이라는 용어를 사용함

<그림 3> 주택매매가격지수와 잠재요인 비교
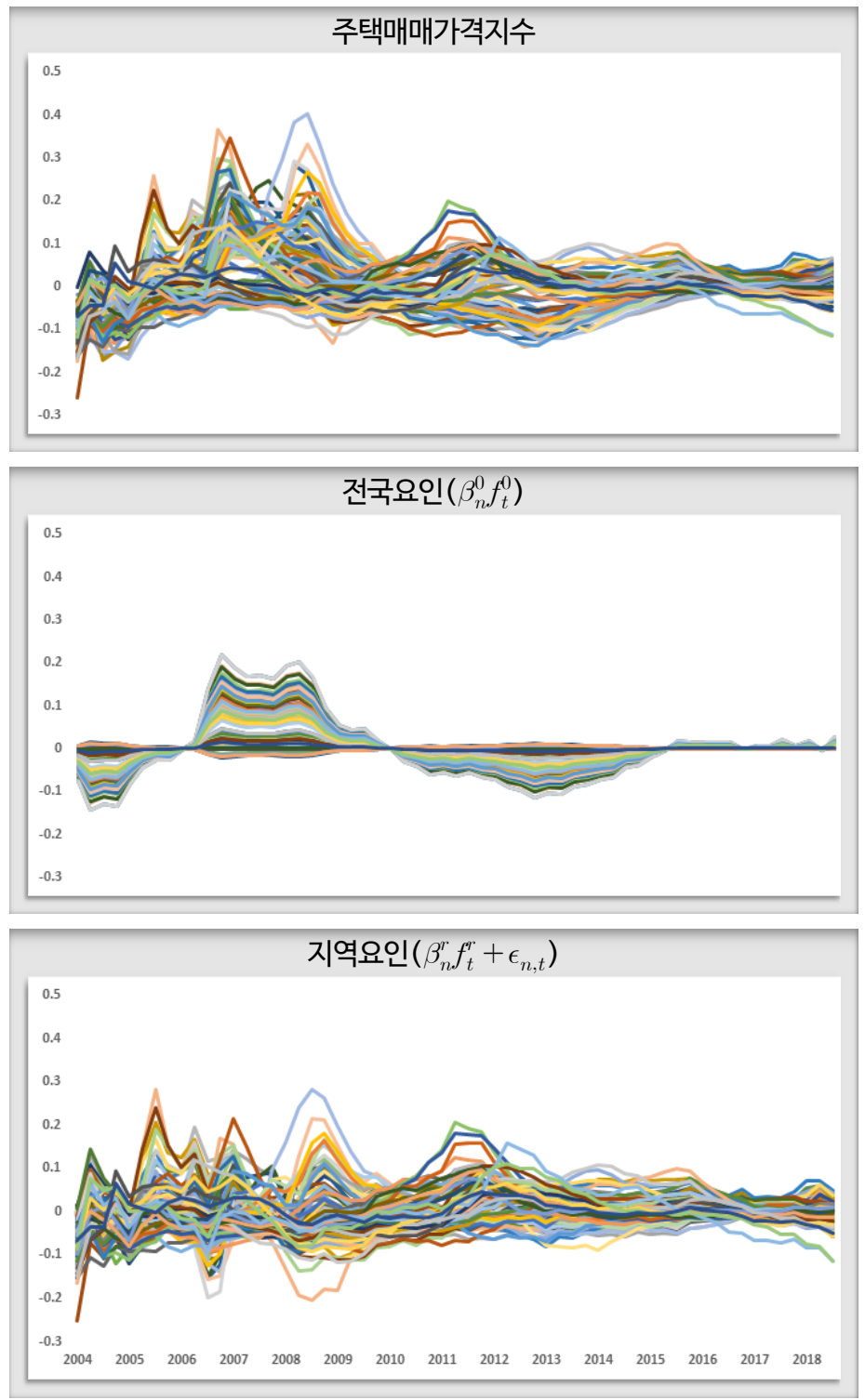

※ 자료 : 주택매매가격지수 변화율 2004Q1-2018Q3 
제1기(2004:Q1-2009:Q4): 주택가격 상하 변화 폭이 상당히 크며, 대부분의 지역이 초기 가격하락을 경험하다 상승하였음

- 전국 주택가격의 추세는 전국요인의 움직임을 상당부분 따라가지만, 주택가격 변화의 지역 별 차별성도 강하기에 지역요인의 역할도 큰 것을 알 수 있음

제2기(2010:Q1-2015:Q2): 전국요인에 의해 하방압력이 있지만 지역요인의 역할이 상대적으로 중요해지기 시작하는 시기임

- 지역요인의 역할이 강해지다 보니 점차적으로 수도권과 비수도권의 주택가격 변화가 상이 하게 나타남. 특히 경남권을 중심으로 지역요인의 상승압력이 강하게 나타나 지역적 주택 시장 상승을 견인함

\section{<그림 4> 전국주택가격과 전국요인}

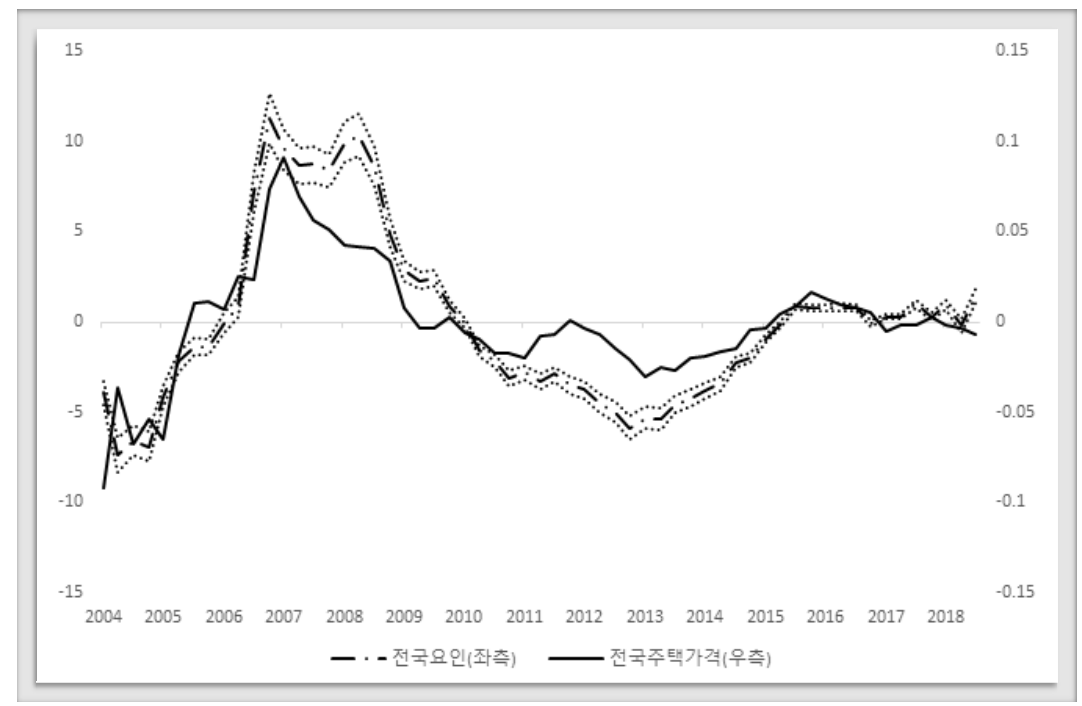

※ 자료 : 2004Q1-2018Q3

- 제2기 동안 전국요인의 흐름은 점차적으로 축소되더니 이 시기 후반으로 가면 전국요인의 역할은 미미할 정도로 사라짐

제3기(2015:Q3-2018:Q3): 주택가격 상승률이 예전에 비해 많이 줄어들었으며 이러 한 변동성의 감소는 전국요인의 영향력 감소에 기인함

- 제3기 각 지역의 주택가격의 흐름은 지역요인에 의해 대부분 결정되며, 최근 2 년간의 전국 
적 주택가격의 비동조화는 제 2 기 때 전국요인이 강함에도 불구하고 발생한 비동조화 현상 과는 그 궤를 달리함

\section{2. 전국요인의 역할 변화}

ㄴ그림4〉는 전국 주택가격(실선)과 전국요인 사후분포의 중앙값(굵은 점선) 그리고 16-84\% 신뢰구간(가는 점선)을 보여주며, 추정된 전국요인 사후분포의 신뢰구간이 중앙값을 중심으로 좁게 분산되어 있어 추정의 결과가 통계적으로 높은 유의성을 가지 고 있음을 나타냄

전국주택가격의 경우 재고주택량이 많은 지역의 가중치에 의해 지수가 결정되는 경향이 큼에도 불구하고 전국요인과 상당히 밀접하게 전 기간 동안 변화하는 것이 관찰됨

- 특히 육안으로 두 수치의 동화 정도는 제 1 기에 상당히 높았으며 상관계수는 0.89 로 상당히 높았으나, 제 2 기에 접어들며 동조화 정도는 점차 약화되는 모습을 보여주더니 제3기 중 최 근 2년 동안은 두 수치가 반대로 움직이는 것이 포착됨

- 각 시기별로 상관계수는 0.89(제1기), 0.65(제2기), 0.09(제3기)로 최근 들어 급격히 낮 아짐

$\square$ 2017년 이래로 전국주택가격은 장기추세 아래로 하락하는 것을 볼 수 있는 반면 전국요 인이 상승하는 것은 주택가격 결정요소 중 전국요인의 상대적 중요성이 점차적으로 하 락하고 있음

〈그림5〉는 제3기에는 제1기에 비해 모든 대상지역에 대한 전국요인의 상대적 중요도가 하락하였음을 보여줌

- 전국요인의 주택가격을 결정하는 상대적 중요성 혹은 설명력은 정량적으로 파악하고, 또한 지역별로 전국요인의 역할은 어떠한 차별성을 보이며 변화하였는지 분석하기 위해 동적요 인모형으로부터 추정된 분산분해 사후분포의 중앙값을 사용함

-〈그림 5〉는 제 1 기(x축)와 제 3 기(y축) 동안 전국요인이 주택가격의 분산 혹은 변동성을 설 명하는 상대적 비율인 분산분해 결과임 


\section{<그림 5> 제1기와 제3기의 전국요인에 대한 분산분해 비교}

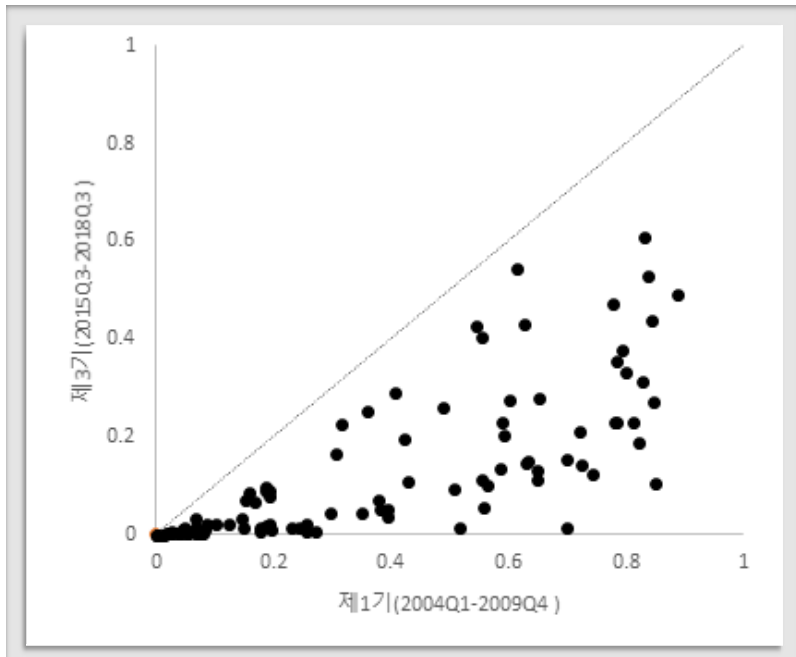

- 각 지역 분산분해의 평균값은 시기별로 제 1 기는 $37.8 \%$ 인 반면 제 3 기는 $12.8 \%$ 로 $25 \%$ p하 락함

$\square$ 이러한 현상은 조사기간 초기에는 주택가격 부침의 많은 부분이 전국요인에 의해 설명 된 반면, 최근 들어 발생하는 주택가격의 비동조화는 지역 주택시장의 고유성이 점차적 으로 가격에 확대 반영되어 발생한 결과임을 보여줌

$\square$ 주택가격의 움직임이 특히 다른 수도권과 부산/울산 지역을 비교하여, 전국요인과 지역 요인의 상대적 차이가 어떻게 진화하여 왔는지 분석하여 봄

$\square$ 우선 수도권에 속한 서울, 경기도, 인천의 주택가격과 잠재요인의 시계열(〈부표1〉)에 따르면 수도권 각 지역의 주택가격은 대체로 전국 주택매매가격지수와 대동소이한 움직 임을 보이고 있음

- 비록 제 3 기에 접어들며 지역요인에 의해 수도권 내의 지역적 차별성을 나타나긴 하지만 이 러한 수도권의 가격변화의 장기적 추세는 전국요인이 주도하는 것으로 보임

- 또한, 전국요인에 의한 분산분해 추정결과 최근 수도권 내에서 전국요인의 중요성이 지역 요인에 비해 감소함 
<그림 6> 지역별 전국요인에 의한 분산분해

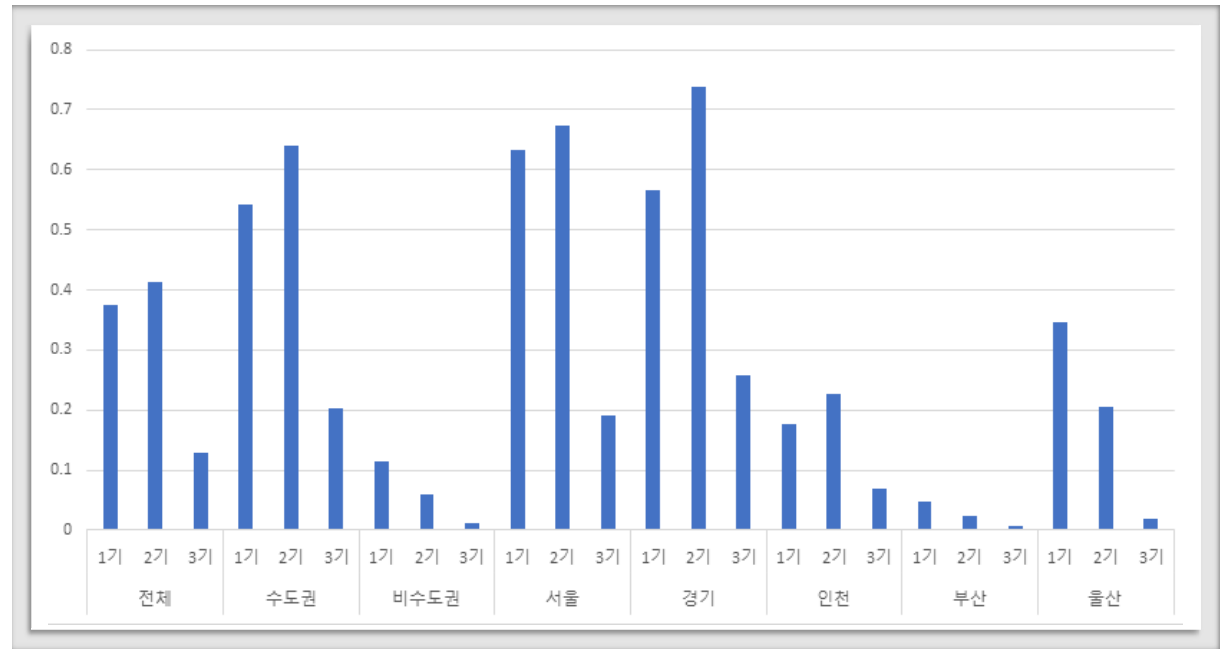

※ 자료 : 2004Q1-2018Q3

하지만 〈그림6〉에 나타나듯이 전국요인의 주택가격에 대한 설명력 정도는 수도권과 비 수도권에서 극명하게 나뉨

- 특히 제 1 기 수도권과 비수도권의 전국요인이 설명력 차이가 4.7배 정도 차이가 났으나 제 2 기에는 10.9 배, 제3기에는 18.5 배로 그 차이가 점점 확대됨

- (수도권, 비수도권)의 전국요인에 대한 분산분해는 제 1 기: $(54.2 \%, 11.6 \%)$, 제 2 기: (64.1\%, 5.9\%), 제3기: $(20.4 \%, 1.1 \%)$ 임

지역적 격차는 초기에는 국가단위의 구조적 충격에 의해 견인되던 통합적 시장이 시간의 경과에 따라 공간적 제약이 심해지며 독립적 시장으로 발전해가고 있는 단면을 보여줌

또한 서울과 경기 내부에서도 전국요인이 설명하는 분산분해의 행정단위별 편차가 존재함

주목할 점은 전국 부동산시장의 흐름과 정부정책을 좌우하는 강남(서초·강남·송파·강동 구)의 주택가격이 서울의 다른 지역보다 지역요인에 의해 견인되는 측면이 크다는 것임

- 문규현 외(2011), 황상연 외(2014)가 주장하듯 강남 주택시장이 전국 주택시장을 선도하는 역할을 하여 전국요인과 상응하는 변화를 보일 것으로 예상되지만, 지역별 분산결과에 따 르면 강남이라는 곳은 사회·경제·문화적으로 지역적 특색이 반영된 차별화 된 주택시장이 
라는 것을 보여줌

$\square$ 마지막으로 인천은 비록 수도권에 포함되어 있지만 전국요인에 의한 분산분해 값을 기 준으로 지역을 분류하자면 수도권과 비수도권 중간에 위치하는 지역이라 최근까지 전국 요인이 주택가격 변동에 영향을 미치고 있음

$\square$ 하지만 〈부표 2〉의 부산과 울산의 경우 전국요인에 대한 분산분해를 기준으로 보았을 때 수도권과는 전혀 다른 양상을 보임

$\square$ 부산의 경우 전 기간에 걸쳐 전국요인이 각 구단위 행정구역의 주택가격에 미치는 영향 이 눈에 띄게 미미하여 다른 지역과 명확히 구분되는 특성을 가짐

- 비록 제1기 초기에 다른 지역들처럼 주택가격이 침체되었으나 이는 전국요인이라기 보다 는 지역요인에 의한 부산 주택 매매시장의 수급상황으로 인해 발생한 결과임

- 부산의 주택시장이 타 지역과 가장 대비되는 시점은 제2기 가격상승기임. 이 시기는 전국 요인에 의해 대부분의 시장이 가격조정을 거쳤으나 부산은 타 지역과 독립적으로 가격이 급등하는 시기를 맞이하였으며, 최근 매매가격 역시 지역요인에 의해 하방으로 움직이고 있음

- 분산분해 결과를 보더라도 부산의 전국요인에 의한 분산분해 사후분포의 중앙값은 각 기간 별로 $4.8 \%, 2.4 \%, 0.8 \%$ 로 추정되어 평균적으로 전국 최하위를 기록함

$\square$ 울산의 경우 조사기간 초기에 수도권과 비슷한 행보를 보였으나, 시간의 경과에 따라 점 차 부산과 비슷하게 지역적 요인이 강하게 작용함

- 제 1 기에는 전국요인에 의해 수도권과의 동조화가 강하게 발생함

- 제 1 기 울산의 전국요인에 의한 분산분해 결과는 $34.5 \%$ 로 서울과 경기를 제외하고 가장 높은 값을 기록

- 제2기에는 전국요인이 가격 하방압력으로 작용함에도 불구하고 강한 지역 동인에 의해 주 택가격 자체는 탈동조화 되는 것처럼 나타난 특이한 시기임

- 제3기는 분산분해 값(1.8\%)이 급격히 낮아졌던 시기로 이는 지역기반산업의 침체로 인해 울산 고유의 지역적 요인이 가격을 주도하여 제 2 기 때와는 다른 순수한 비동조화 현상이 시작되는 시점임 


\section{3. 전국요인 및 지역요인 변동 분석}

2010년 이후 전국 및 각 지역 주택시장의 가격변동을 설명하는 전국요인이 약화되면서 지역요인에 의한 설명력이 강화

- 지역요인 영향력의 강화는 주택시장의 구조적이고 근본적인 변화와 더불어 수급의 불균형, 정부의 규제 및 부양정책, 지역개발 정책 등 여러 가지 요인이 지역 차별적으로 작용한 결과

- 전국 및 지역요인의 변동은 기간별 구분이 가능하지만, 이에 영향을 미치는 요소인 주택시 장의 구조적변화, 수급불균형 등은 여러 기간에 걸쳐 나타나므로 각 요소에 대한 전반적이 고 통합적인 분석이 필요

ㅁ (주택보급률과 인구·가구구조) 주택보급률 상승으로 ‘지으면 팔리는 시대’에서 주택공 급과잉시대로 전환과 더불어 인구증가둔화 및 가구 수 급증 등 주택시장의 구조적 변화 가 진행

전국 평균 주택보급률이 $100 \%$ 를 넘어서면서 절대적인 공급부족의 상태가 해소되었지 만, 수도권과 비수도권의 주택보급률은 점진적으로 격차가 커지면서 전국요인의 약화에 영향을 미침

- 2017년 전국 주택보급률4)은 $103.3 \%$ 로, 서울(96.3\%), 경기(99.5\%)는 아직 $100 \%$ 이하인 반면, 비수도권의 주택보급률은 $107.9 \%$ 를 초과

- 1-2인 가구가 폭발적으로 늘어나면서 소형주택 선호가 급증하는 등 전반적인 주거 트렌드 가 크게 변화하고 있으며, 증가속도에 있어서도 지방과 광역시 그리고 수도권이 현저한 격 차를 보이고 있음

- 2006-2014년 수도권 1인가구는 138만가구에서 214만 가구로 증가(증가율 55.1\%), 반 면 지방의 1 인가구는 118 만에서 172 만으로 증가(증가율 $46 \%$ )하였으며, 지역별 증감의 격차도 각각 매우 다르게 나타남

4) 신주택보급률(다가구를 한 주택으로 보지 않고 개별가구 모두를 주택수에 포함하는 구분거처, 1 인 가구 반영) 기준 

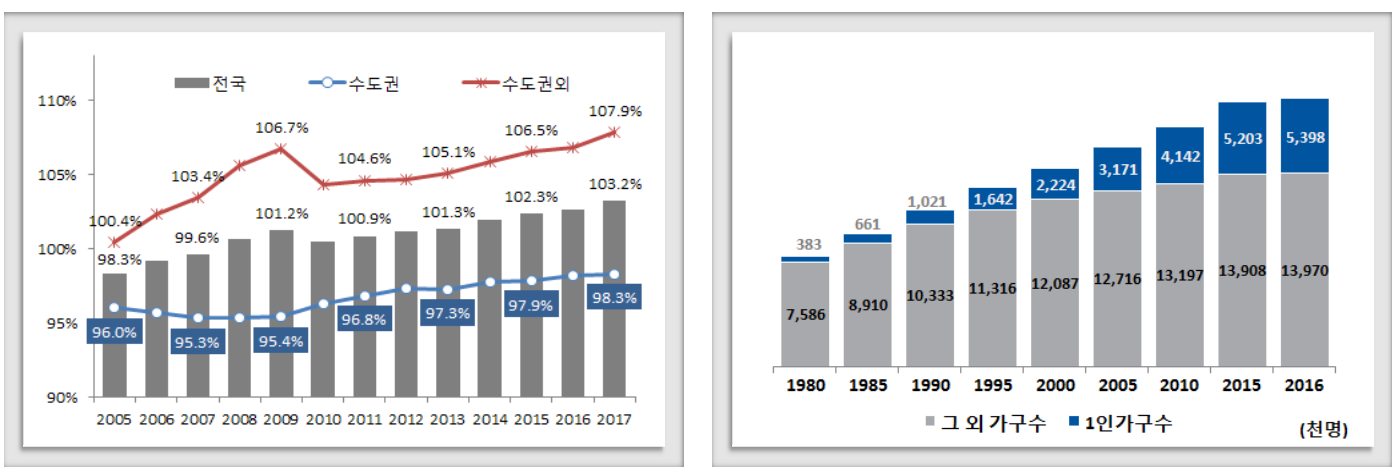

※ 자료 : 국토교통부, 주) 시도별 주택보급률은 2017년 기준

ㅁ (전세수요와 매매수요) 2010년 초 수도권과 지방의 전세가와 매매가가 다르게 변동함 에 따라 전세수요와 매매수요의 방향이 차별화 됨

- 2010-2013년 수도권의 경우 주택가격 하락세가 장기화됨에 따라 주택구입 실수요가 전세 수요로 전환되면서 전세난이 심화됨

- 수도권 주택가격은 2010년 -1.7\%, 2011년 +0.5\%, 2012년 -2.8\%로 하락 추세반면, 전 세가격은 2011년 수도권을 중심으로 $12.3 \%$ 의 급등세를 기록한 후 2012-13년에도 2 3\% 상승세 지속

- 2010-2014년 지방 주택시장은 상승세가 나타났으며, 일부 광역시의 경우 전세가 상승에 이어 매매가가 상승하면서 전세수요가 매매수요로 전환되면서 주택가격이 급격히 상승함

- 부산의 경우 실거래가 기준 2010-2012년 48.7\% 상승하였으며, 울산은 2011-2012년 1 년 간 주택가격은 $13.9 \%$, 아파트는 $18.1 \%$ 급상승

\section{<그림 8> 수도권 비수도권 매매가격 및 전세가격 추이}

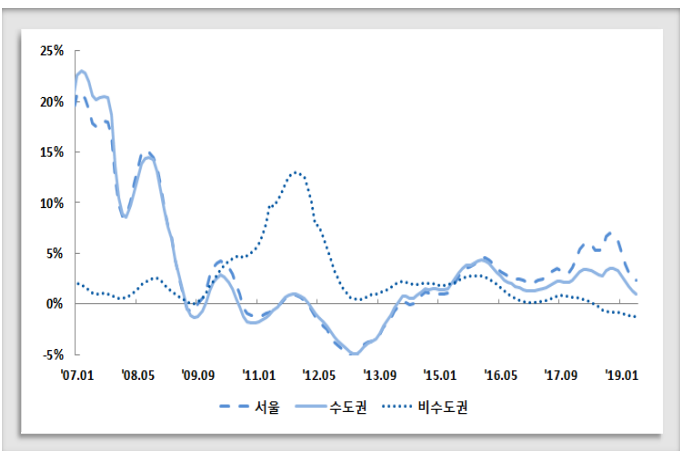

$※$ 자료 : 국토교통부

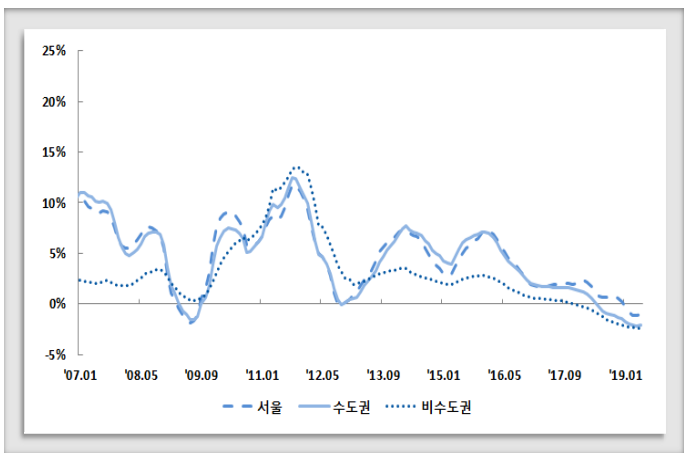

※ 자료 : 국토교통부 
(수급불균형) 2000년대 중반 전반적 주택시장과열로 인한 공급과잉으로 적체되기 시 작한 미분양은 2009년 최대로 확대

- 미분양이 절정에 달한 2009년에는 대부분의 미분양이 지방에서 발생하였으며, 준공 후 미 분양 또한 일정수준을 지속적으로 유지

- 2015년 이후 지방을 중심으로 미분양이 다시 증가하는 양상이 나타나고 있음

- 각 지방의 미분양 물량은 시기와 지역에 따라 차별적인 양상을 보이고 있으며 최근 이러한 경향이 점점 확대되는 추세

2009년 발생한 막대한 미분양이 해소되고 최근 다시 증가하는 과정에서 나타나는 수급 불균형은 각 지방주택시장의 지역요인을 강화

<그림 9> 미분양 및 준공 후 미분양 추이

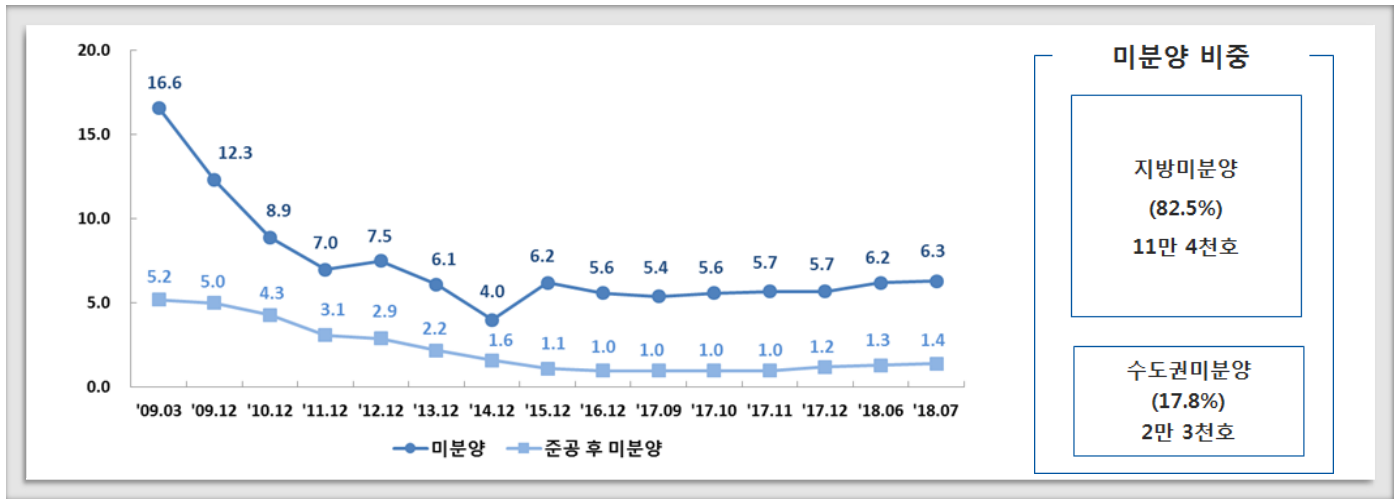

<그림 10> 과거 미분양 추이 및 지역별 미분양 최근 추이

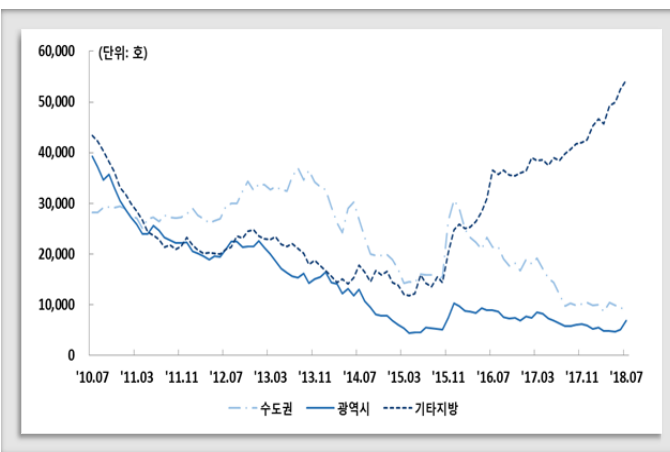

※ 자료 : 국토교통부

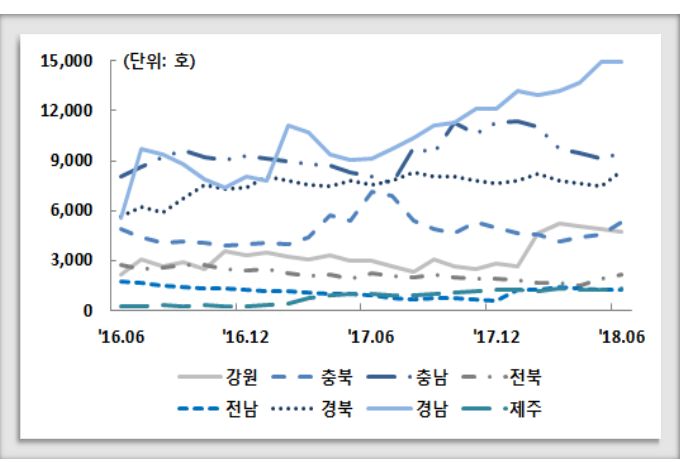

※ 자료 : 국토교통부 
$\square$ (주택정책) 2010년을 전후한 주택대출규정책 및 여러 가지 주택시장 규제 정책이 수도 권에 집중되면서 수도권과 지방의 비동조화에 영향을 미쳤으며, 2015년경의 규제 완화 는 이런 경향을 심화

- 2009년 LTV·DTI가 수도권을 대상으로 은행권과 비은행권 모두 강화됨(표2). 또한, 2009 년 지방시장에 급증한 미분양을 해결하기 위해 발표된 다양한 대책은 비수도권의 비동조화 심화에 영향을 줌

- 이후, 2014년 양도세 중과 폐지 및 재산세, 종부세 감면 혜택 등을 주요 골자로 한 4.1 부 동산 대책은 금융위기 이후 저금리 기조와 맞물려 주택시장에 풍부한 유동성을 공급함

- 2014년 청약요건 및 재개발 재건축 규제가 완화되면서 분양시장을 중심으로 수도권의 주 택시장의 침체가 빠르게 다시 상승세로 전환됨

$\square$ 2010년과 2015년을 전후하여 주택시장 규제 정책 및 부양 정책이 수도권과 비수도권 에 차별적으로 시행되면서, 수도권이 견인하는 전국요인이 약화되고 지역요인이 강화되 는데 영향을 미침

\section{<그림 11> 서울 수도권 및 지방 주택가격 추이}

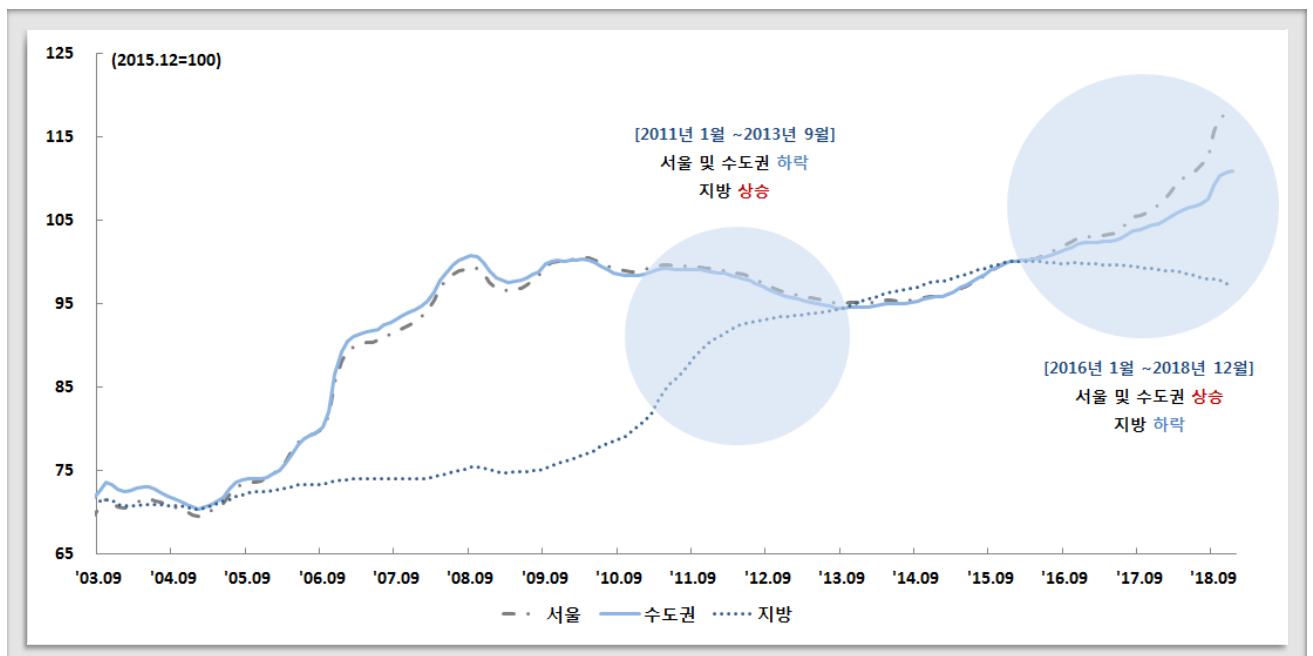

※ 자료 : 한국감정원 
<표 2> 주택대출 규제 강화조치 2009년 중

\begin{tabular}{|c|c|c|c|c|}
\hline & & 시행시기 & 적용대상 & 내용 \\
\hline \multirow{2}{*}{ 은행권 } & LTV & 2009.7월 & 수도권 전지역 & $\begin{array}{c}\text { 담보인정비율 축소 } \\
60 \% \rightarrow 50 \%\end{array}$ \\
\hline & DTI & 2009.9월 & 수도권 전지역 & $\begin{array}{l}\text { 총부채상환비율 적용대상 확대 } \\
\text { (투기지역 } \rightarrow \text { 수도권 전 지역) }\end{array}$ \\
\hline 비은행권 & $\begin{array}{l}\text { LTV } \\
\text { DTI }\end{array}$ & 2009.10월 & 수도권 전지역 & $\begin{array}{c}\text { 담보인정비율 축소 및 } \\
\text { 총부채상환비율 적용대상 확대 }\end{array}$ \\
\hline
\end{tabular}

\section{<그림 12> 2004년 이후 부동산시장 주요 정책}

\section{4년 2008년}

('05.02) 재건축 안전진단 강화 등

('05.05) 양도세 및 보유세 강화 등

('05.08) 재산세 과표적용률 상향 조정, 종합부동산세 대상 강화 등

('06.03) 재건축 개발이익 환수제, 재건축 안전진단 기준 강화, 고과주택 대출 요건 강화 등

('06.11) LTV 규제 강화

('08.06) 지방 미분양 LTV 완화, 한시적 취·등록세 감면 등

('08.08) 수도권 전매제한 기간 완화, 재건축 의무 후분양제 폐지 등

\section{9년 2013년}

('09.03) 양도세 중과세 폐지 ('09.09) DTI규제 수도권 확대 ('10.04) 4.23 미분양 해소 대책 ('10.07) 부동산 거래 활성화 대책 ('11.07) 다주택자 양도세 중과 폐지 ('12.07) 강남 3 구 투기과열지구 해제 ('13.02) 취득세 감면 한시적 연장 등 ('13.04) 생애최초 주택구입 취득세 면제

('13.07) 수도권 보금자리 신규지정 중단, 공공분양 축소 등

('13.08) 취득세 영구인하 등

('13.12) 행복주택 공급 등

\section{4년 2018년 현재}

('14.07) LTV·DTI 규제 완화 ('14.09) 재건축 연한 30년으로 단축 등 ('16.08) 공공택지 및 공급물량 축소 등 ('16.11) 서울 경기 등 청약제도 강화 등 ('17.06) 조정지역대상 선정 등 ('17.08) 8.2 부동산 종합대책 ('17.09) 투기과열지구 추가 선정 등 ('17.10) 가계부채 종합대책

('18.01) 재건축 초과이익 환수제 부활, 황DTI도입 등

('18.04) 양도소득세 강화 ('18.06) 종합부동산세 개편

※ 자료: 국토교통부

(지역개발 및 경제환경) 다양한 지역개발 및 비수도권 광역시의 도심재개발은 서로 다른 각 지역의 경제상황과 맞물려 지역요인을 더욱 강하게 만드는 요인으로 작용함

- 국토균형발전을 위한 계획의 일환으로 세종시를 비롯한 전국에 정부종합청사 및 공공기관 지방이전이 2011년부터 본격화 되면서 비수도권의 지역요인을 강화하는데 영향을 미친 것 으로 추정

- 공공기관이 이전함과 동시에 다양한 혁신도시 등이 활발히 진행되고, 광역시를 중심으로 낙후된 도심의 재개발이 추진되면서 지역개발로 인한 지방 도시들의 가격 상승 현상이 뚜 렷해짐 
$\square$ 또한, 2015년 이후 일부지역을 제외한 대부분의 지역경기 침체로 전반적인 주택수요가 감소하면서 주택시장 활황기에 계획된 공급물량이 미분양으로 전환되면서 각 지역별 주 택경기의 차별화가 심화됨

- 울산·경남 지역은 기반산업의 경기침체 및 미분양 급증으로 2016년 이후 주택시장 침체가 지속

- 반면, 광주, 대전, 대구지역은 교통환경 개선 및 주거환경 개선이 구 단위로 진행됨에 따라 구별로 각기 다른 상승세를 보임

- 지역경기가 급격히 침체된 군산, 공급과잉의 영향력이 큰 창원 등의 지역은 최근 들어 주택 경기가 급격히 침체

- 평창 올림픽으로 일시적으로 주택가격이 상승한 강원도나 지역개발에 따라 각각의 지역이 차별적으로 움직이는 경기도 및 충청도 등은 같은 지역권내에서도 다양한 양상이 나타남

$\square$ 살펴본 것과 같이 각 지역의 다양한 개발계획 및 경제상황은 지역 주택시장의 고유성과 맞물려, 전국요인이 약화 및 지역요인의 강화에 영향을 미칠 것으로 추정됨

\section{4. 잠재요인 변동 관점에서의 부산·울산 주택시장 분석}

$\square$ 부산은 전 조사기간 동안 지역요인이 타 지역에 비해 가장 강하게 나타나고 있었으며, 최 근에 들어서는 더욱 강해짐

$\square$ 울산은 광역시 중에서는 지역요인이 약한 편이었으나 최근에는 매우 강해지는 경향을 보임

- 따라서 부산/울산 주택시장을 구분하여 각 시장의 특징을 분석해볼 필요가 있음

\section{■ 부산 주택시장}

$\square$ 부산주택시장의 전국요인 약화는 부산지역의 고유성에 기인하고 있는 것으로 보이며, 지역요인의 강화는 도심재개발 및 혁신도시를 비롯한 지역개발 등이 큰 영향을 미친 것 으로 보임 
(인구유출 및 주택노후화) 부산은 지속적으로 인구가 감소하고 있으며, 노령인구비율 및 노후주택비율이 타 광역시에 비해 높은 수준으로 주택시장의 기본적인 환경이 타 지 역 대비 차별성이 많음

- 부산은 양산·김해 신도시 개발 및 산업경기 침체 등으로 인해 인구가 유출되고 있으며, 노 령인구 비율도 이전부터 가장 높은 수준

- 부산 2005년 이후 인구증가율(-0.31\%)은 전국평균(+0.54\%) 및 5대 광역시 평균(+0.26\%) 에 비해 하락세가 뚜렷함

- 부산 65세 이상 노령인구비율(15.40\%)은 전국평균(13.59\%) 및 5대 광역시 평균(12.22\%) 에 비해 확연히 높은 수준을 유지 중

- 노후주택비율 또한 2000년대부터 시작된 도심재개발에도 불구하고 전국에서 가장 높은 수준

- 부산은 한국전쟁으로 인한 파괴가 없어 기본적으로 노후주택의 비율이 전국에서 가장 높 고, 한국전쟁 당시와 이후 산업개발시기 대규모 인구가 급격히 몰리면서 집이 먼저 생기 고 도로가 나중에 생기는 극심한 난개발등으로 인해 교통이 매우 불편해짐

- 부산의 30년 이상 노후주택비율(21.92\%)은 전국평균(16.80\%) 및 5대 광역시평균(15.63\%) 에 비해 현저히 높음

<표 3> 인구증가율 지역별 비교

\begin{tabular}{|c|c|c|c|c|}
\hline \multicolumn{2}{|c|}{ 지역 } & 2005년 총인구수(합계) & 2016년 총인구수(합계) & 연평균 인구증가율 \\
\hline 전국 & & $47,041,434$ & $51,269,554$ & $0.54 \%$ \\
\hline \multirow[t]{7}{*}{ 수도권 } & & $22,621,232$ & $25,390,486$ & $0.84 \%$ \\
\hline & 경남 & 3,040,993 & 3,339,633 & $0.62 \%$ \\
\hline & 대구 & $2,456,016$ & $2,461,002$ & $-0.09 \%$ \\
\hline & 광주 & $1,413,644$ & $1,501,557$ & $0.41 \%$ \\
\hline & 대전 & $1,438,551$ & $1,535,445$ & $0.49 \%$ \\
\hline & 울산 & $1,044,934$ & $1,166,033$ & $0.80 \%$ \\
\hline & 부산 & $3,512,547$ & $3,440,484$ & $-0.31 \%$ \\
\hline
\end{tabular}

※ 자료 : 통계청 


\section{<그림 13> 부산 인구증감 추이}

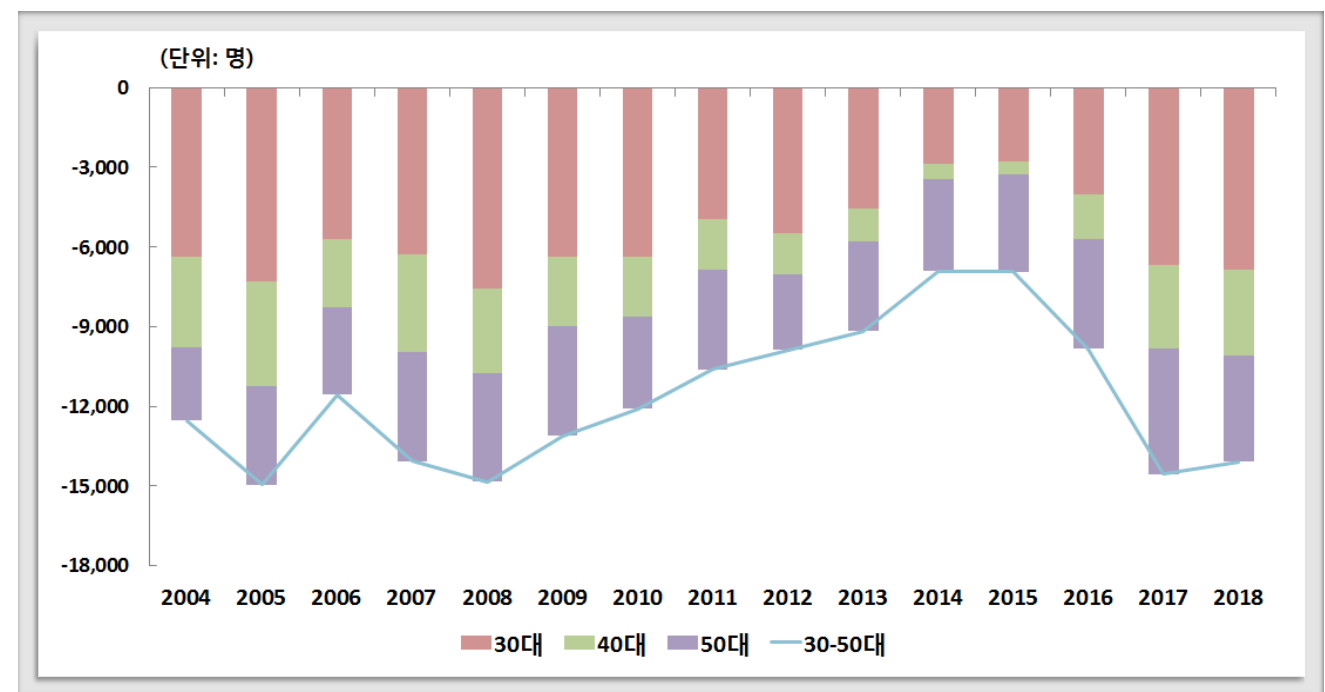

※ 자료: 국토교통부

$\square$ (부산 대규모 도심재개발) 부산 도심지역내 대규모 재개발 및 혁신도시 이전, 국제물류 도시개발 등이 2005년을 전후하여 본격화 되면서, 가격상승의 기대감이 증가 전세가와 매매가의 상승을 견인

- 부산 정비사업예정구역은 2010년 당시 약 26,327 천 $\mathrm{m}^{2}$ 로 전체 시가화 면적의 $13 \%$ 로 광역 시중 가장 높은 수준(표4-1)

- 비율상으로 당시 대구(7\%), 서울(9\%), 인천(10\%) 보다 높고, 대전(13\%)과는 비율은 비슷 하지만 면적(대전; 11,720 천 $\mathrm{m}^{2}$ )에서 2배 이상의 차이를 보임

- 주거환경개선사업 및 주택재개발사업을 포함한 도심재개발의 면적이 서울 $\left(32,759 \mathrm{~m}^{2}\right)$ 다 음가는 규모이며, 이는 도시의 면적, 인구 등을 고려해 볼 때 지방광역시중 당시 가장 압 도적인 규모의 도심재개발

$\square$ 2006년 이후 본격화된 부산의 혁신도시는 2011년에 즈음하여 마무리 단계에 접어들 면서 해당 지역의 주택시장에 영향을 미침

- 부산에서 진행되는 혁신도시는 총 4 개로 약 13 개 행정기관의 이전이 예정되어 있으며, 혁 신도시의 보상 및 공사는 해당지역 주택시장에 영향을 미침

- 원래 야적장으로 활용되던 부산의 센텀시티는 교통이 매우 용이한 입지에도 불구하고, 정 부가 개입한 혁신도시 계획으로 인해 뒤늦게 지역개발이 이루어진 사례로 지역개발로 인한 
도시전반의 긍정적 변화를 잘 보여줌

- 센텀시티는 상업시설과 주거, 그리고 첨단산업단지 등이 조화된 성공적인 혁신도시로 주 변 주택가격을 비롯한 해운대 전반의 주택시장에 영향을 미쳤을 뿐 아니라 부산자체의 이

미지 제고에도 영향을 미침

- 부산은 바다에 인접하고 평지가 부족하여 재개발 이외에도 매립지, 항만, 야적장 등 유휴부 지를 활용하는 것이 중요

- 예를 들어 해운대구의 마린시티는 20 년간 비어있던 매립지를 고급 주거지로 개발하여 지 역의 주택시장에 큰 영향을 미침

북항 재개발사업을 비롯하여 부산 전체에 걸친 도심재개발 사업은 계속 진행되고 있으 며 이러한 대규모 도심재개발은 향후 지속적으로 지역요인강화에 영향을 미칠 것으로 보임

<표 4-1> 부산정비사업예정 개요

\begin{tabular}{c|c}
\hline 구분 & 면적 $\left(\right.$ 천 $\left.\mathrm{m}^{2}\right)$ \\
\hline 주거환경개선 사업 & 4,512 \\
\hline 주택 재개발 사업 & 13,021 \\
\hline 주택 재건축 사업 & 4,127 \\
\hline 도시환경 정비사업 & 3,944 \\
\hline 사업유형 유보구역 & 718 \\
\hline 합계 & 2,6327 \\
\hline
\end{tabular}

※ 자료 : 국토교통부
<표 4-2> 부산혁신도시 개발개요

\begin{tabular}{c|c|c}
\hline 지구명 & 규모 $\left(\right.$ 천m $\left.\mathrm{m}^{2}\right)$ & 개발방향 \\
\hline 동삼지구 & 616 & 해양수산 클러스터 \\
\hline 문현지구 & 102 & 금융 클러스터 \\
\hline 센텀지구 & 61 & 영화영상 클러스터 \\
\hline 대연지구 & 156 & 공동주거 클러스터 \\
\hline 계 & 935 & \\
\hline
\end{tabular}

※ 자료 : 국토교통부

(멸실확대 및 공급부족) 2010 2014년 주택노후 등으로 인해 부산지역 멸실주택은 크게 확대, 반면 아파트 공급량은 2009 2012년 사이 크게 감소하면서 수급불균형 상태 심화

- 노후화된 주택이 도심에 많이 분포한 부산 주택시장의 특성이 대규모 도심재개발과 맞물리 면서 멸실주택이 다수 발생

- 2010-2014 누적 멸실은 2만 9천호로 재고주택 대비 멸실주택 비율이 지방광역시 중 가 장 높음

- 한편 부산지역의 주택공급은 2009-2012년간 가장 공급물량이 낮음, 이로 인해 전반적인 수급불균형이 발생 
주택금융연구 VOL 3

- 이는 당시 부산주택시장의 급격한 가격상승을 야기함과 동시에 지방요인을 더욱 강화시키 는데 영향을 미친 것으로 추정

<표 5> 주택멸실 및 멸실비율 추이

\begin{tabular}{c|c|c|c|c|c|c|c|c}
\hline & 2010 & 2011 & 2012 & 2013 & 2014 & 5 년합계 & 재고(2015) & 멸실/재고 \\
\hline 부산 & 5,885 & 4,988 & 5,698 & 7,143 & 5,023 & 28,737 & $1,162,000$ & $2.5 \%$ \\
\hline 대구 & 3,451 & 3,332 & 3,196 & 3,700 & 3,580 & 17,259 & 738,000 & $2.3 \%$ \\
\hline 광주 & 1,524 & 1,265 & 3,531 & 1,497 & 2,340 & 10,157 & 487,000 & $2.1 \%$ \\
\hline 대전 & 2,894 & 1,851 & 1,121 & 1,057 & 1,403 & 8,326 & 469,000 & $1.8 \%$ \\
\hline 울산 & 1,595 & 1,395 & 1,393 & 1,746 & 1,438 & 7,567 & 358,000 & $2.1 \%$ \\
\hline
\end{tabular}

※ 자료 : 통계청

<그림 14 > 지방광역시 입주물량 추이

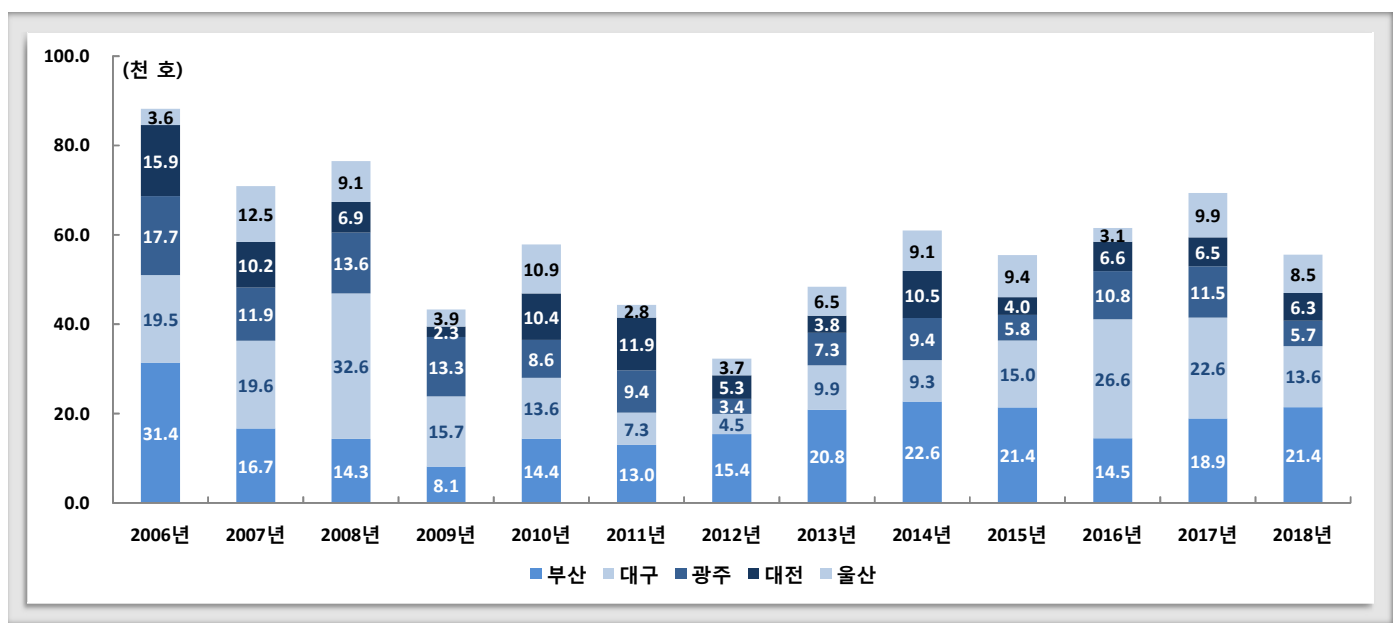

※ 자료 : 국토교통부

$\square$ (교통환경개선 부산지역별 영향력) 국제산업물류도시 추진 및 도심재개발 등으로 인해 교통환경 개선 지역 중심으로 가격 상승

물류중심 도시개발을 위한 국제산업물류도시 개발로 인해 상대적으로 낙후된 부산 강서 권역을 중심으로 교통환경이 크게 개선 
혁신도시 등 도심개발사업 진행으로 부산 지역 전반적으로 교통 및 도시환경 개선의 효 과가 나타나 전세가 및 매매가격의 상승을 견인

- 부산은 서부산권(북·사하·강서·사상), 동부산권(동래·해운대·금정·기장), 중부산권(중·서· 동구 등 8개 구) 로 구분

- 국제물류도시 개발로 인한 교통환경 개선*은 서부산권 특히 사상구와 사하구의 지가 및 주 택시장에 영향을 미침

*부산-거제연결도로(2010.11) / 부산신항배후철도(2010.11) 완공

<그림 15> 혁신도시 위치 및 강성국제산업물류도시 교통망 개선 개요

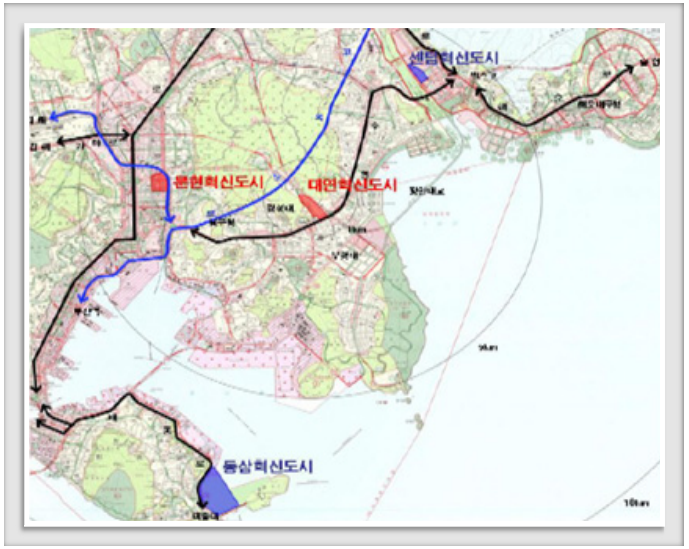

※ 자료 : 국토교통부

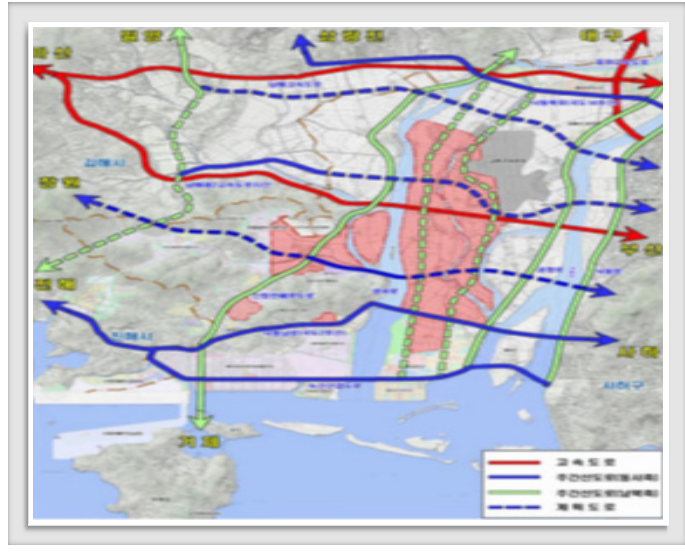

※ 자료 : 국토교통부

<그림 16> 부산 각지역 주택가격 연도별 상승률 및 누적 상승률(05-17)

\begin{tabular}{|l|r|r|r|r|}
\hline & 2009 년 & 2010년 & 2011년 & 2012년 \\
\hline 부산 전체 & 4.08 & 10.59 & 15.91 & -2.34 \\
\hline 중구 & 0.97 & 5.88 & 13.29 & -0.03 \\
\hline 서구 & 2.71 & 4.37 & 8.42 & -0.59 \\
\hline 동구 & -0.78 & 1.76 & 4.59 & 1.97 \\
영도구 & 6.58 & 6.81 & 9.20 & -1.52 \\
\hline 부산진구 & 3.16 & 10.77 & 14.41 & -1.40 \\
남구 & 2.42 & 9.49 & 14.86 & 0.61 \\
\hline 연제구 & 3.14 & 8.14 & 12.80 & -1.17 \\
수영구 & 6.12 & 6.12 & 11.84 & -0.33 \\
\hline 해운대구 & 5.95 & 11.70 & 16.70 & -4.70 \\
\hline 금정구 & 1.87 & 6.11 & 17.54 & -0.66 \\
동래구 & 3.15 & 9.70 & 12.99 & -1.58 \\
\hline 기장군 & 4.39 & 10.11 & 13.76 & 0.37 \\
\hline 북구 & 6.17 & 18.35 & 23.54 & -6.86 \\
\hline 사상구 & 5.71 & 19.20 & 22.75 & -2.36 \\
\hline 사하구 & 4.42 & 12.93 & 22.01 & -6.75 \\
\hline
\end{tabular}

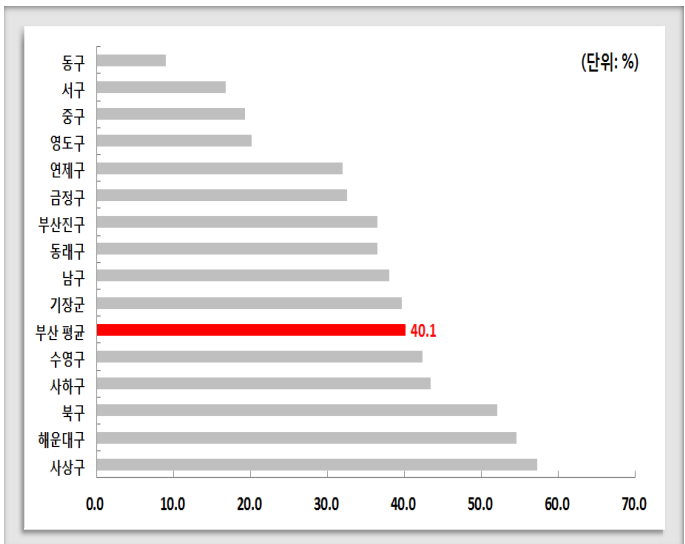

※ 자료 : 한국감정원 


\section{■ 울산 주택시장}

$\square$ 울산 또한 주택시장의 지역요인은 부산에 비해서는 낮고 전국요인이 높은 편이었으나, 2010년을 지나면서 지역요인이 강화됨

$\square$ 울산의 지역요인의 강화는 인구구조 및 경제상황, 주택시장 수급 등 다양한 요인들이 영 향을 미친 것으로 보임

ㅁ (인구 및 가구 증가) 울산지역은 2010년 9월을 기점으로 인구의 순유입이 증가, 1-2인 가구 증가속도 또한 다른 지역보다 높았음

- 다른지역 대비 매우 이례적으로 인구의 유입이 큰 편이었으며 유입된 인구 또한 주택 실수 요층인 30-40대가 주류를 이룸

- 또한 1-2인 가구의 빠른 증가로 2000-2010년 인구증가율은 6.8\% 인데 반해 가구수 증가 율은 $22.7 \%$ 의 증가율을 보임

- 2010-2014간의 인구 유입은 2015이후 다시 유출로 돌아선 반면 1-2인 가구 비율은 지속 적으로 증가하여 2017년에는 50\%를 넘어섬

<그림 17> 울산 인구증감 추이 및 가구규모별 비율변동 추이
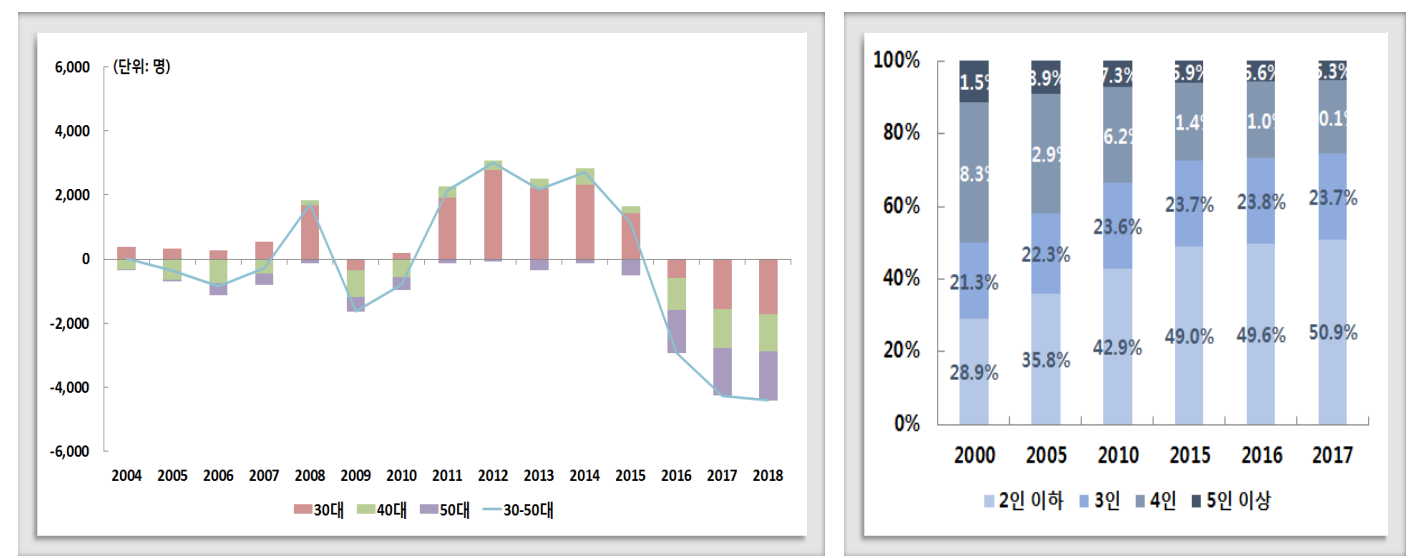

※ 자료 : 국토교통부

모소득대비 낮은 매매가) - 울산은 소득대비 주택구입 부담은 광역시중 광주를 제외하고 는 가장 낮은 수준이며 현재도 과거의 상태를 유지 중

- 울산의 경우 주택금응공사 주택구입부담지수5)가 2011년 1분기 50.5로 지방 주요 대도시

5) 주택금융공사에서 매분기 발표하는 주택구입부담지수(또는 '주택구입능력지수', Korea Housing Affordability 
중 가장 낮은 수준이며 이는 2019년에도 유지

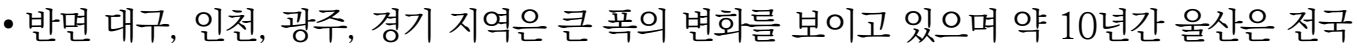
에서 부산과 더불어 주택구입부담의 변화가 가장 작음

ㅁ (전국평균과 상이한 전세가율) - 전세가와 매매가의 비율 또한 전국의 평균수준과 큰 괴 리를 보였으나 2016년 이후 비율이 역전되었으며 이는 지역요인 강화의 요인으로 작용 했을 것으로 추정

- 울산의 전세가격은 2008-2009년 67\%에서 70\%이상으로 상승하였으며 이당시 전국 평균 전세가율은 50\%대였으나 이런 비율의 격차는 2016년에 접어들면서 역전됨

<그림 18> 지역별 K-HAl 비교

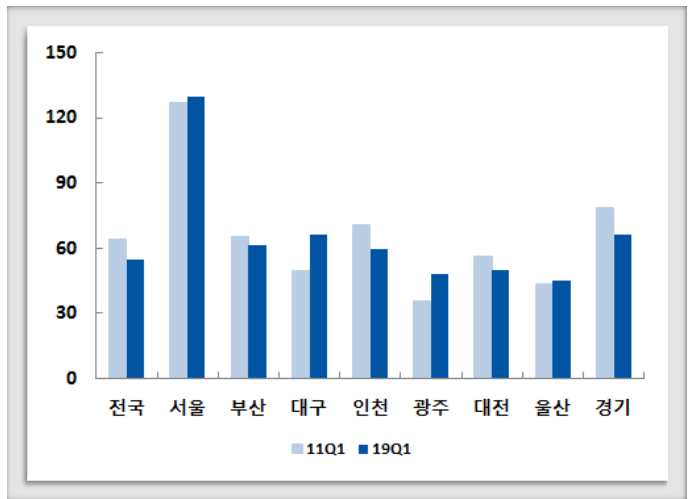

※ 자료 : 한국주택금융공사
<그림 19> 아파트 전세가/매매가 추이

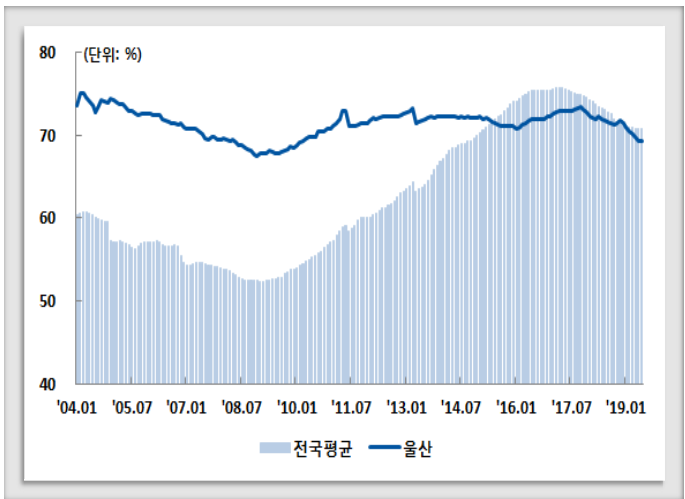

※ 자료 : 한국감정원

ㅁ (전세수요 및 매매수요) 2010년 초반에 매매가격과 전세가격이 동반상승하면서 전세 수요가 매매수요로 전환되어 가격 상승이 가속화되는 경향이 컸으나 최근에 동반 하락 추세를 보임

- 2010년을 전후하여 울산지역의 전세가격은 매우 큰 상승세를 보이면서 이전부터 타 지역 대비 차이가 적었던 매매가와의 차이가 더 줄어들었으며, 이로 인해 전세에서 매매로의 수 요전환이 크게 나타남

- 단기간에 일어난 전세수요의 매매수요 전환으로 인한 수요의 확대는 울산지역의 높은 가격 상승 및 지역강화 요인의 확대에 영향을 미쳤을 것으로 예상

Index)는 주택가격, 대출조건, 소득수준 등을 고려하여 가계의 주택구입 관련 대출상환 부담 정도를 나타낸 지표 
$\square$ (경기침체 및 미분양) 최근 들어 지역경기가 침체되고 주택가격이 크게 하락하면서 수 요가 크게 위축되고 있으며 이로 인해 2015년 경 거의 소멸된 미분양이 다시 큰 폭의 증 가세를 보임

- 조선·중공업 등 지역기반산업이 침체에 접어들면서 지역경기회복에 대한 전망이 어두워지 고 있으며 이로 인해 주택수요가 크게 위축

- 2018년 울산 양대 산업단지인 울산미포산단과 온산산단 가동률이 $80 \%$ 대로 하락하고, 현 대중공업은 2,400 명에 달하는 희망퇴직을 추진하는 등 지역경기가 크게 나빠지고 있으며 향후 전망도 어두움

- 이로 인해 수요가 크게 위축되면서 주택시장이 급격히 침체*되고 있으며, 이에 반해 이전 에 예정된 아파트는 계속 공급되고 있어 앞으로 미분양이 더욱 늘어날 가능성이 큼

* 2018년 울산의 주택거래량은 5년 평균치보다 50\% 이상 하락하였으며, 아파트 가격은 1 년간 $11 \%$ 이상 하락 5 대 광역시중 최대낙폭을 보임

- 울산과 같은 산업도시는 지역산업의 경기에 따라 주택시장의 수요가 큰 영향을 받는데 반 해 공급은 수요와 시차가 생기므로 단기간에 확대된 수요가 축소될 경우 미리 예정된 공급 물량의 소화가 어려운 경향이 다른 지방에 비해 큰 경향이 있음

<그림 20> 지역별 매매전세 변동추이

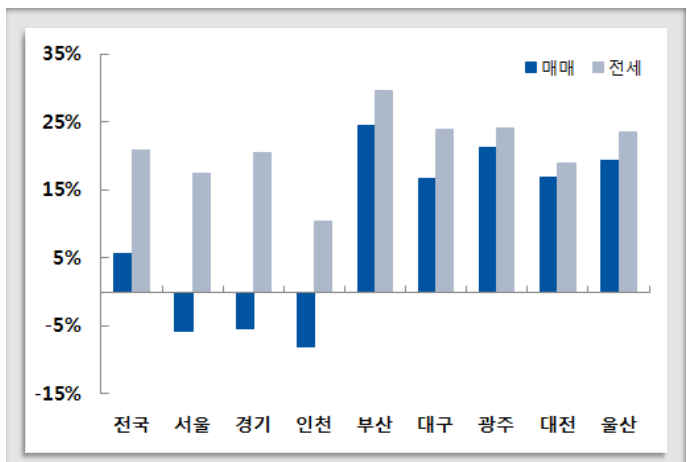

※ 자료 : 한국감정원

\section{<그림 21> 울산 미분양 추이}

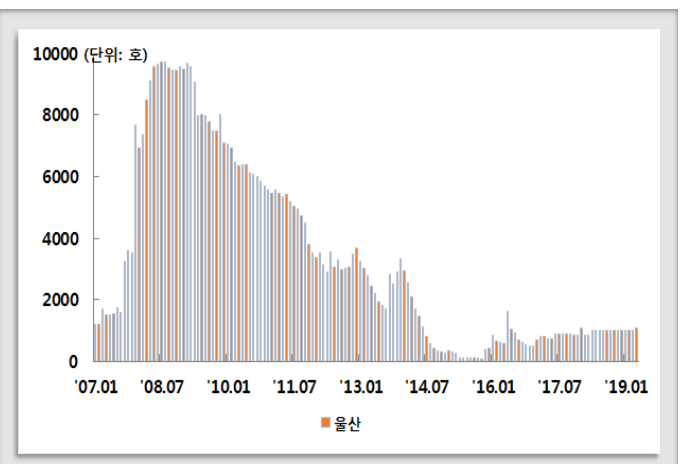

※ 자료 : 한국감정원 


\section{$\mathrm{V}$. 결론}

본 연구는 수도권 및 5대 광역시를 중심으로 주택가격의 동조화 그리고 비동조화 현상을 알아보고자 하였음

- 기존의 많은 연구가 동조화를 단순히 주택가격 자체의 움직임을 기본으로 정의하는 것과는 달리 (1)주택가격을 동조화를 유발하는 전국요인과 (2)비동조화 흐름을 설명할 수 있는 지역 요인으로 분리하여, 지역별 주택가격의 공통된 움직임을 설명할 수 있는 정제된 두 잠재요 인으로 수도권과 부산/울산을 비교분석하였음

- 주택가격의 움직임에만 초점을 맞춘 기존 주류연구의 경우 주택가격 변화 자체에 동조화 요인과 비동조화 요인이 섞여 있는 것을 감안하지 않음. 만일 두 지역의 주택가격이 동시에 상승하더라도 가격상승의 주체가 지역요인이라면 두 지역은 동조화의 영향이라 보기 힘듦

$\square$ 지역별 주택가격의 움직임을 결정하는 전국 및 지역요인을 분리 추출하고자 동적요인모 형(Dynamic Factor Model)을 사용하였으며, 동조화의 정도를 전국요인에서 비동조 화의 요인을 지역요인에서 찾고자 함

- 전국요인의 추출을 위해 서울 강남지역을 선도지역으로 설정하고 강남지역 주택가격은 전 국요인과 양의 방향으로 민감도가 결정되어야 된다고 가정하였으며, 나머지 광역시 및 경 기도 지역도 선도지역을 설정하여 각 권역별 지역요인(권역요인)을 추정함

$\square$ 2004년 이후 전국요인과 지역요인의 상대적 역할은 시기별로 큰 변화를 보임. 2009년 까지는 전국요인이 동인하는 동조화 현상이 전국적으로 강하였으나 이후 점차적으로 지 역요인이 상대적으로 강화되어 2015년 이후 비동조화 현상은 더욱 뚜렷해짐

- 특히, 수도권과 부산/울산지역의 비동조화가 두드려지게 나타났으며, 역사적으로 부산과 울산은 수도권 이외의 지역과 비교를 하더라도 지역요인이 상당히 강하게 작용하는 독립적 인 주택시장으로 판단됨

ㅁ 2010년 전후하여 지역요인이 강화되는 경향은 주택시장의 구조적이고 근본적인 변화 와 더불어 수급의 불균형, 정부의 규제정책, 지역개발 정책 등 여러 가지 요인이 지역 차 별적으로 작용한 결과 
- 2009년을 기점으로 전국 평균 주택보급률이 $100 \%$ 를 넘어서고 최근에는 $110 \%$ 에 가까워 지면서 지으면 팔리는 시대에서 공급과잉 시대로 전환됨

- 또한, 인구유출입 및 1 인 가구 급증 등이 지역에 따라 상이하게 나타나면서 주택시장의 구 조적 변화가 진행

- 한편, 2010년 초 수도권과 비수도권의 전세가와 매매가가 다르게 변동하고, 공급과잉으로 적체되기 시작한 지방 미분양이 2009년 최대로 확대 되면서 지역요인이 강화되는데 영향 을 미침

- 2010년을 전후하여 수도권에 집중된 규제정책은 수도권과 지방의 비동조화에 영향을 미쳤 으며, 다양한 지역개발 및 비수도권 광역시의 도심재개발은 서로 다른 각 지역의 경제상황 과 맞물려 지역요인을 더욱 강하게 만드는 요인으로 작용함

실증분석결과에 따르면 부산과 울산은 최근 들어 지역요인이 강화되는 경향이 지방광역 시 중 가장 강하게 나타났음

무산주택시장의 전국요인 약화는 부산지역의 고유성에 기인하고 있는 것으로 보이며, 지역요인의 강화는 도심재개발 및 혁신도시를 비롯한 지역개발 등이 큰 영향을 미친 것 으로 보임

- 부산은 전국에서 가장 인구감소가 두드러졌으며, 노후주택 및 노령인구비중 또한 높은 편 으로 전반적인 수요가 전국 평균보다 낮게 나타날 조건을 가지고 있었으며 2000년대 말 주 택공급도 매우 부족

- 그러나 2000년대 말 도심재개발 및 서부산권의 개발 등이 본격화됨에 따라 주거 및 교통 환경이 개선되면서 수요가 확대되면서 가격이 급격히 상승하다가 최근에 규제 및 공급과잉 으로 가격이 하락

- 살펴본 것과 같이 부산은 기본적인 주택수요에 있어서 다른 지역과 차이가 있는 상태에서 지역개발로 인한 주택가격 급상승이 일어나면서 원래 강했던 지역요인이 더욱 강해지는데 영향을 미침

$\square$ 울산 지역요인의 강화는 인구구조 및 경제상황, 주택시장 수급불균형 등 다양한 요인들이 영향을 미친 것으로 보임

- 울산은 지방 대도시 중 이례적으로 2010년 경 주택실수요층인 30-40대의 인구유입이 두 
드러졌으며, 평균소득이 높아 주택구입부담이 전국에서 가장 낮은 수준을 10 년 이상 유지

- 울산의 지역요인 강화가 2010 년을 기점으로 강화된 것은 울산의 지역적 고유성이 영향을 미친 것으로 보임

- 또한, 최근의 주택가격 하락은 산업도시의 특성상 지역기반산업 침체에 의한 수요축소로 인한 것으로 이러한 지역특성은 향후에도 지역요인 강화에 영향을 미칠 것으로 보임

$\square$ 계량모형하에서 분석이 가능한 정량적 관점의 주택시장 비동조화현상은 그 현상의 분석에 있어서 정성적인 관점을 가질 수밖에 없는 한계가 존재

본 연구는 주택시장의 구조적인 변화의 관점에서 시기별로 차별적인 주택시장 비동조화 경향을 분석하기 위한 시도로 나름의 의미가 있음

$\square$ 주택시장 비동조성의 강화 경향과 이유를 분석한 본 연구의 결과는 향후 전국단위 주택 정책과 지역단위 주택정책의 차별적인 수립·관리가 왜 필요한지에 대한 근거로 활용이 가능할 것으로 보임

<부표 1> 수도권

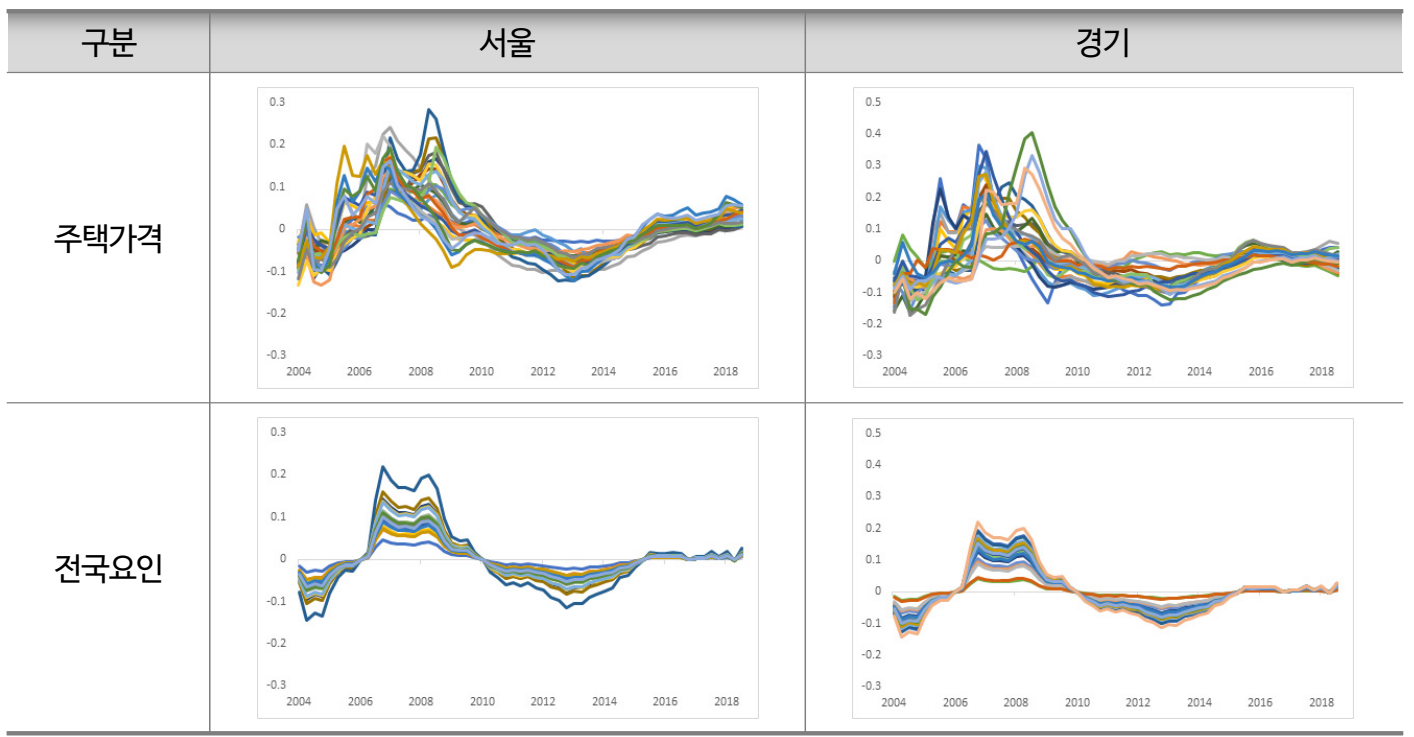


주택금융연구 VOL 3

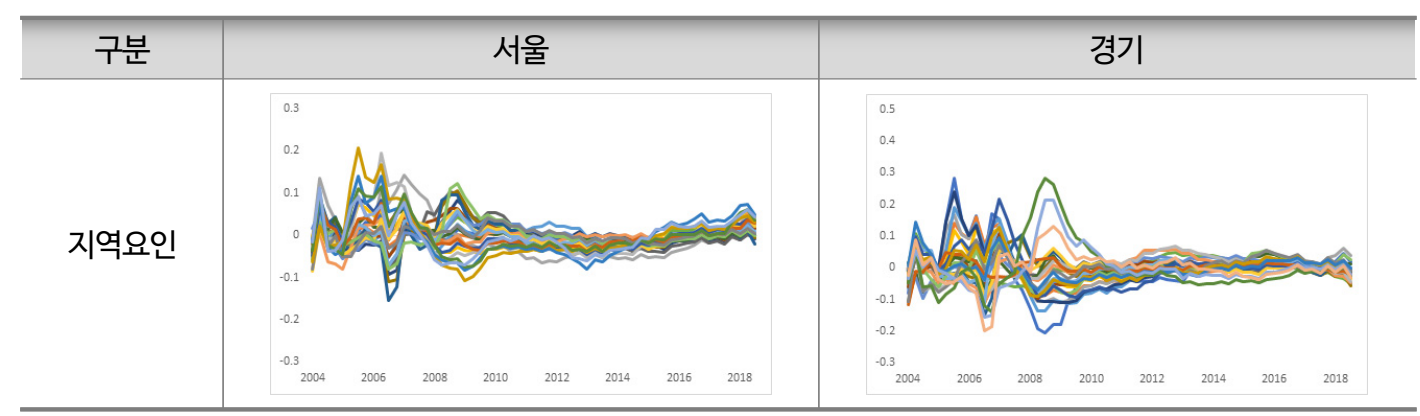

<부표 2> 부산, 울산

전국요인




\section{참고문헌}

이용만·이상한, 2004, 강남지역의 주택가격이 주변지역의 주택가격을 결정하는가?. 국토계획, 39(1), 73-91.

조무상·이종하, 2018, 주택가격 변동요인 분석. 산업경제연구, 31(3), 1031-1055.

문규현·이동희, 2011, 강남아파트시장은 전국아파트시장을 선도하는가? . 산업경제연구, 24(1), 115-136. 신용상, 2015,국내 주택시장의 수도권-비수도권 간 탈동조화 현상과 정책시사점, (3),1-81.

Pomogajko, K., \& Voigtländer, M., 2012, Co-movement of house price cycles-a factor analysis. International Journal of Housing Markets and Analysis, 5(4), 414-426.

Otrok, C., \& Whiteman, C. H., 1998, Bayesian Leading Indicators: Measuring and Predicting Economic Conditions in lowa. International Economic Review, 39(4), 997.

Del Negro, M., \& Otrok, C., 2007, 99 Luftballons: Monetary policy and the house price boom across U.S. states. Journal of Monetary Economics, 54(7), 1962-1985. 